\title{
Reclassification of Pterulaceae Corner (Basidiomycota: Agaricales) introducing the ant-associated genus Myrmecopterula gen. nov., Phaeopterula Henn. and the corticioid Radulomycetaceae fam. nov.
}

Caio A. Leal-Dutra ${ }^{1,5}$, Gareth W. Griffith ${ }^{1 *}$ (D, Maria Alice Neves², David J. McLaughlin ${ }^{3}$, Esther G. McLaughlin ${ }^{3}$, Lina A. Clasen ${ }^{1}$ and Bryn T. M. Dentinger ${ }^{4}$

\begin{abstract}
Pterulaceae was formally proposed to group six coralloid and dimitic genera: Actiniceps (=Dimorphocystis), Allantula, Deflexula, Parapterulicium, Pterula, and Pterulicium. Recent molecular studies have shown that some of the characters currently used in Pterulaceae do not distinguish the genera. Actiniceps and Parapterulicium have been removed, and a few other resupinate genera were added to the family. However, none of these studies intended to investigate the relationship between Pterulaceae genera. In this study, we generated 278 sequences from both newly collected and fungarium samples. Phylogenetic analyses supported with morphological data allowed a reclassification of Pterulaceae where we propose the introduction of Myrmecopterula gen. nov. and Radulomycetaceae fam. nov., the reintroduction of Phaeopterula, the synonymisation of Deflexula in Pterulicium, and 53 new combinations. Pterula is rendered polyphyletic requiring a reclassification; thus, it is split into Pterula, Myrmecopterula gen. nov., Pterulicium and Phaeopterula. Deflexula is recovered as paraphyletic alongside several Pterula species and Pterulicium, and is sunk into the latter genus. Phaeopterula is reintroduced to accommodate species with darker basidiomes. The neotropical Myrmecopterula gen. nov. forms a distinct clade adjacent to Pterula, and most members of this clade are associated with active or inactive attine ant nests. The resupinate genera Coronicium and Merulicium are recovered in a strongly supported clade close to Pterulicium. The other resupinate genera previously included in Pterulaceae, and which form basidiomes lacking cystidia and with monomitic hyphal structure (Radulomyces, Radulotubus and Aphanobasidium), are reclassified into Radulomycetaceae fam. nov. Allantula is still an enigmatic piece in this puzzle known only from the type specimen that requires molecular investigation. A key for the genera of Pterulaceae and Radulomycetaceae fam. nov. is also provided here.
\end{abstract}

Keywords: Molecular systematics, Pleurotineae, corticioid fungi, coralloid fungi, Icavarioid fungi, coral mushroom, Aphyllophorales, attine ants, fungus-farming ants, asexual fungi

\footnotetext{
* Correspondence: gwg@aber.ac.uk

'Institute of Biological, Environmental and Rural Sciences, Aberystwyth

University, Aberystwyth", Ceredigion SY23 3DD, UK

Full list of author information is available at the end of the article
}

(c) The Author(s). 2020 Open Access This article is distributed under the terms of the Creative Commons Attribution 4.0 International License (http://creativecommons.org/licenses/by/4.0/), which permits unrestricted use, distribution, and reproduction in any medium, provided you give appropriate credit to the original author(s) and the source, provide a link to the Creative Commons license, and indicate if changes were made. The Creative Commons Public Domain Dedication waiver (http://creativecommons.org/publicdomain/zero/1.0/) applies to the data made available in this article, unless otherwise stated. 


\section{INTRODUCTION}

The history of Pterulaceae begins with the hesitant proposal of the genus Pterula (hereinafter abbreviated as Pt.) in the early 19th century by Fries $(1821,1825,1830)$. The typification of this genus was addressed by Lloyd (1919) and this was followed by discussion between Doty (1948), Donk (1949), and Rogers (1949, 1950). Ultimately Corner (1952c) provided a thorough discussion of the timeline of Fries' decisions, which was later confirmed with further clarification by (Donk 1954; Donk 1963).

The number of species in Pterula grew during the late 19th and early 20th centuries, with Léveille, Patouillard, Hennings, Saccardo, Lloyd, Spegazzini, and Berkeley being the most active in the naming of taxonomic novelties of Pterula in this period (Corner 1950, 1970). Lloyd (1919) devoted an entire chapter to discuss the taxonomy of the genus. However, the major contribution to the genus was made by E. J. H. Corner who added at least 45 new taxa (Corner 1950, 1952b, 1966, 1967, 1970). Corner (1950) created the Pteruloid series in Clavariaceae to group, besides Pterula, other genera with coralloid basidiome and dimitic hyphal system. The Pteruloid series was raised by Donk (1964) to Pteruloideae, a subfamily of Clavariaceae. Pterulaceae was formally proposed by Corner (1970) including the genera from the original Pteruloideae: Allantula, Deflexula, Dimorphocystis (= Actiniceps), Parapterulicium, Pterula and Pterulicium (hereinafter abbreviated as Pm.) (Corner 1950, 1952a, 1952b, 1970) (Fig. 1).

Following Corner's reclassifications, the major changes in Pterulaceae have resulted from molecular phylogenetic analyses. Actiniceps was shown within Agaricales to be distantly related to Pterulaceae and Parapterulicium was removed to Russulales (Dentinger and McLaughlin 2006; Leal-Dutra et al. 2018). Four resupinate genera were transferred to Pterulaceae: Aphanobasidium, Coronicium, Merulicium, and Radulomyces (Larsson 2007; Larsson et al. 2004) and, finally, the new poroid genus Radulotubus was proposed in the family (Zhao et al. 2016) (Fig. 2).

The ecological roles of Pterulaceae are not well understood, most being classified from superficial observations as saprotrophs, growing on wood or leaf litter, with wood decay potentially being the ancestral state. Whilst many species are found inhabiting soil or litter, two species are reported to associate with living plants, namely Pterula cf. tenuissima, endophytic in asymptomatic leaves of Magnolia grandiflora, and Pterulicium xylogenum, causal agent of culm rot disease of bamboo (Munkacsi et al. 2004; Villesen et al. 2004; Harsh et al. 2005) and possibly also a pathogen of sugarcane (Corner, 1952b).

Pterulaceae has attracted more attention recently following the discovery of two distinct symbionts of fungus-farming ants in the genus Apterostigma being included in several phylogenetic and ecological studies (Matheny et al. 2006; Hibbett 2007; Dentinger et al. 2009; Binder et al. 2010; Leal-
Dutra 2015). Despite the absence (hitherto) of any sexual morph, phylogenetic analyses placed both species, Pterula nudihortorum and Pt. velohortorum [as G2 and G4 in Dentinger (2014)], in a strongly supported clade within Pterulaceae (Munkacsi et al. 2004; Villesen et al. 2004).

Whilst these earlier phylogenetic studies did not focus on resolving evolutionary relationships of the genera, they did demonstrate that the coralloid genera of Pterulaceae are clearly polyphyletic. Amongst the morphological characters previously used to separate the genera, but now known to be phylogenetically unreliable, is the orientation of basidiome growth that differentiates Pterula from Deflexula and the presence of a corticioid patch at the base of the basidiome in Pterulicium (Corner 1950, 1952a, 1970). Therefore, the reclassification of Pterulaceae is required to restore the monophyly of the genera.

We aimed to clarify the phylogenetic relationships of the various genera within Pterulaceae through collection of new samples during fieldwork campaigns in Brazil and additionally sampling of fungarium specimens. This has yielded sequence data from many specimens not included in previous phylogenetic analyses, permitting a comprehensive reappraisal of the phylogeny of Pterulaceae. Here we present a proposal for a new classification based on the phylogeny inferred from three nuclear loci (nrITS, nrLSU and RPB2), including representatives of all genera currently accepted in Pterulaceae except Allantula. Despite several attempts for recollecting Allantula in its type locality, the monotypic genus is still only known from the type specimen collected by Corner (1952a).

\section{METHODS}

\section{Collections and morphological observations}

Several field campaigns between 2011 and 2017 have obtained new specimens from $>15$ locations in nine states across Brazil (Amazonas, Espírito Santo, Minas Gerais, Pará, Paraíba, Paraná, Rio de Janeiro, Rio Grande do Sul and Santa Catarina). The samples were dried in a low-heat food dehydrator and deposited at Aberystwyth University (ABS), Instituto Nacional de Pesquisas da Amazônia (INPA), Jardim Botânico do Rio de Janeiro (RB), Royal Botanic Gardens - Kew (K), Universidade Federal do Oeste do Pará (HSTM) and Universidade Federal de Santa Catarina (FLOR). Morphological identification and taxonomy of Pterulaceae are treated sensu Corner. Microscopic observations followed the methods described in Leal-Dutra (2015) and Leal-Dutra et al. (2018).

DNA extraction, amplification, cloning and sequencing DNA was extracted from dried basidiomes or freeze-dried cultures by first grinding with liquid nitrogen and then lysis in CTAB buffer (100 mM Tris- $\mathrm{HCl} \mathrm{pH} 8.0,1.4 \mathrm{M} \mathrm{NaCl}, 20$ 

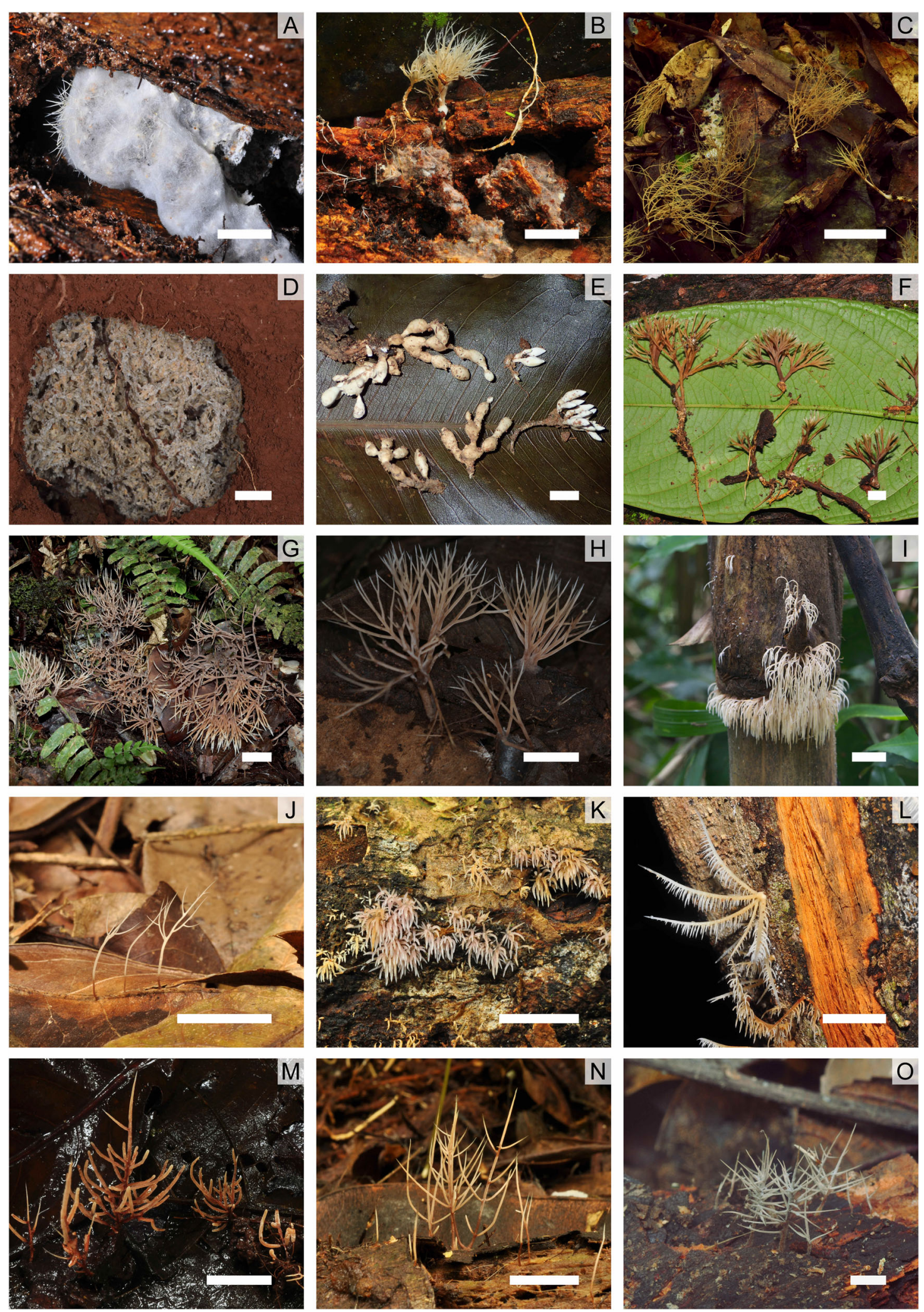

Fig. 1 (See legend on next page.) 
(See figure on previous page.)

Fig. 1 Diversity of coralloid genera of Pterulaceae. a-f: Myrmecopterula [A: Apterostigma sp. nest with M. velohortorum (RC12; CALD170307-02)* with M. sp. SAPV1 (F82; CALD170307-02)* growing on top of the garden veil; b: M. sp. (F99, HSTM-Fungos 9930); C: M. sp. (F138, FLOR 63724); d: Apterostigma sp. nest with M. nudihortorum (TRS111004-04)*; e: M. moniliformis (CJL585)*; f: M. sp. (F71, HSTM-Fungos 9943)]. g-h: Pterula [G: Pt. cf. loretensis (RLC273, K(M) 205,553)*; h: Pt. cf. verticillata (K(M) 27,119)]. i-l: Pterulicium [I: Pm. secundirameum (RB 575794); j: Pm. aff. fluminensis (FLOR 56379); k: Pm. lilaceobrunneum (M117, FLOR 56455). I: Pm. sprucei (F68, HSTM-Fungos 9940)]. M-O: Phaeopterula [m: Ph. sp. (F7, HSTMFungos 9944); n: Ph. stipata (M15, FLOR 56375); o: Ph. juruensis (F33, FLOR 63719)]. Close inspection of B and C reveal the basidiomes to be growing from a granular substrate resembling substrate of ants' fungus garden. Photos $\mathbf{d}$, e and $\mathbf{g}$ kindly provided by Ted Schultz, Susanne Sourell and Michael Wherley respectively. Bars $=1 \mathrm{~cm} .{ }^{*}$ Samples not deposited

mM EDTA, 2\% CTAB), clean-up with chloroform:isoamyl alcohol (24:1), precipitation with isopropanol (0.6 vol.) and a final wash with $70 \%$ ethanol. Partial sequences of the nrITS, nrLSU and RPB2 were amplified by PCR using the primer pairs listed on Table 1 and following the cycling conditions in the original publications. PCR products were purified using $2 \mathrm{U}$ of Exonuclease I (Thermo Fisher Scientific) and 0.2 U FastAP Thermosensitive Alkaline Phosphatase (Thermo Fisher Scientific) per $1 \mu \mathrm{l}$ of PCR product, incubated at $37^{\circ} \mathrm{C}$ for $15 \mathrm{~min}$, followed by heat inactivation at $85^{\circ} \mathrm{C}$ for $15 \mathrm{~min}$. The samples were then sent for Sanger sequencing at the IBERS Translational Genomics Facility (Aberystwyth University) or Jodrell Laboratory (Royal Botanic Gardens, Kew). The same PCR primers were used for sequencing; additional primers were used to sequence the nrLSU and RPB2 (Table 1).
Chromatograms were manually checked and sequences assembled and edited using GENEIOUS 10.0.2 (Kearse et al. 2012). Samples presenting indels were cloned using pGEMT Easy Vector Systems (Promega) into Subcloning Efficiency DH5 $\alpha$ Competent Cells (Invitrogen). Up to five clones from each sample were amplified and sequenced as above. For each sample clone sequences were aligned to generate one or more consensus sequences and polymorphisms were replaced by respective IUPAC code for ambiguous nucleotide; in cases where indels were found, two different sequences were saved (Leal-Dutra et al. 2018).

Moreover, 27 sequences of nrITS (4), nrLSU (10) and RPB2 (13) were mined from 13 previously assembled and unpublished genomes using NCBI BLAST+ package v2.7.1 (Camacho et al. 2009). Two sequences of each Pterulaceae genus were used as query and the best hit based on the
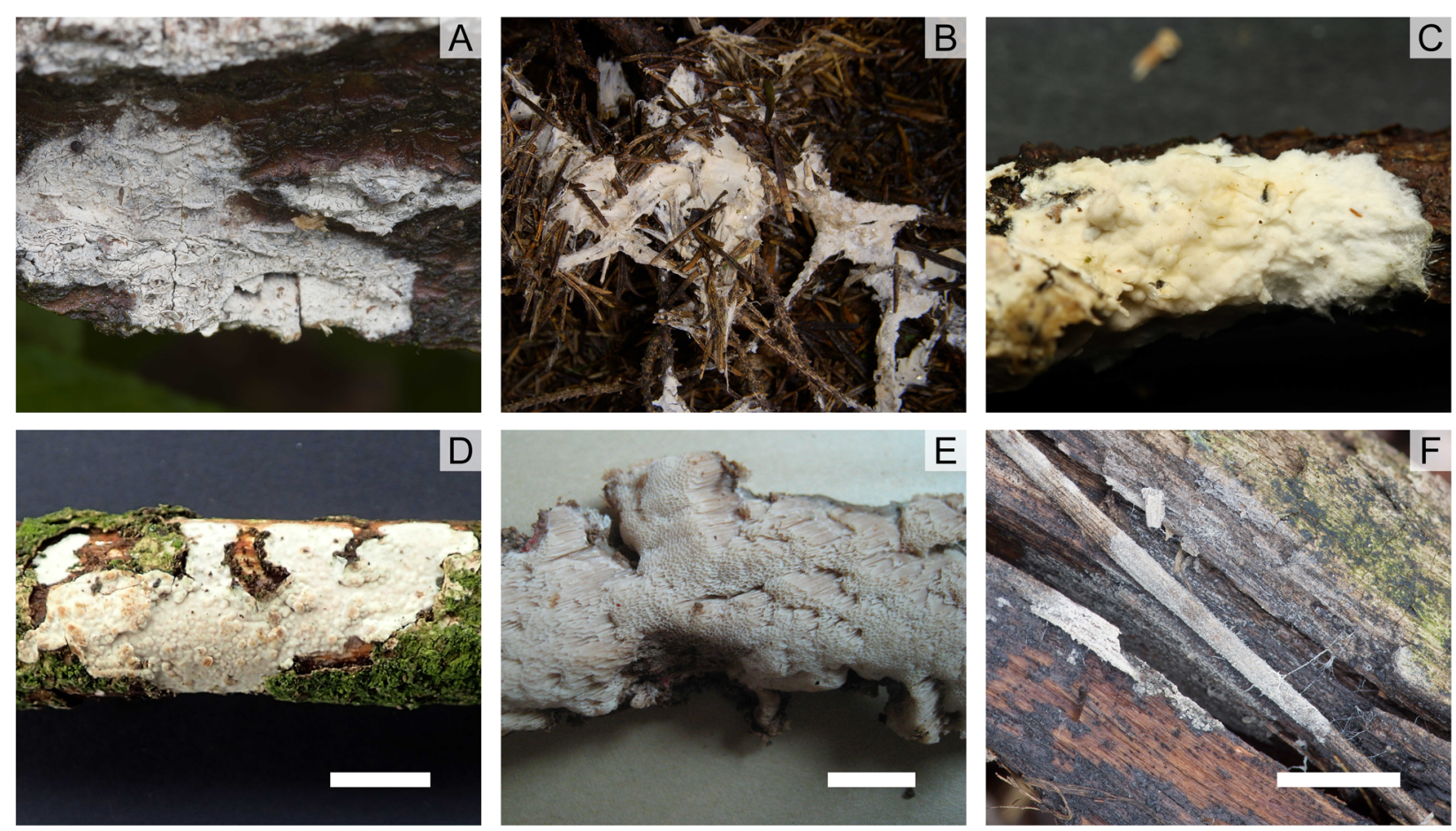

Fig. 2 Corticioid genera of Pterulaceae (a-c) and Radulomycetaceae (d-f). A: Coronicium alboglaucum*. b-c: Merulicium fusisporum* . d Radulomyces confluens (ABS 53). e: Radulotubus resupinatus (Dai 15,315 - BJFC). f: Aphanobasidium cf. pseudotsugae (ABS 54). Photos kindly provided by L. Zíbarová (a and f), S. Blaser (b and c), D.J. Harries (d) and C.L. Zhao (e). Bars = $1 \mathrm{~cm}$. * Samples not deposited 
Table 1 Primers used in this study for PCR and sequencing

\begin{tabular}{lllll}
\hline Primer & Region & Application & Sequence & Reference \\
\hline ITS8F & nrlTS & PCR and sequencing & AGTCGTAACAAGGTTTCCGTAGGTG & (Dentinger et al. 2010) \\
ITS6R & nrlTS & PCR and sequencing & TTCCCGCTCACTCGCAGT & (Dentinger et al. 2010) \\
LR0R & nrLSU & PCR and sequencing & ACCCGCTGAACTTAAGC & (Vilgalys and Hester 1990) \\
LR7 & nrLSU & PCR and sequencing & TACTACCACCAAGATCT & (Vilgalys and Hester 1990) \\
LR5 & nrLSU & Sequencing & TCCTGAGGGAAACTTCG & (Vilgalys and Hester 1990) \\
fRPB2-5F & RPB2 & PCR and sequencing & GAYGAYMGWGATCAYTTYGG & (Liu et al. 1999) \\
bRPB2-7.1R & RPB2 & PCR and sequencing & CCCATRGCYTGYTMCCCATDGC & (Matheny 2005) \\
bRPB2-6F & RPB2 & Sequencing & TGGGGYATGGTNTGYCCYGC & (Matheny 2005) \\
\hline
\end{tabular}

combination of e-value and bit score was selected; the same hit should usually appear for all query sequences. In one case (sample KM190547), more than one optimal hit was found; the subject sequences were compared for occurrence of indels and treated as virtual clones (VC). These sequences are included in the dataset (Table 2). The sequences generated in this study have been submitted to GenBank (Table 2).

\section{Phylogenetic analyses}

A preliminary maximum-likelihood (ML) analysis was conducted with the sequences generated in this study alongside GenBank sequences to find the best outgroup for Pterulaceae based on previous studies (Dentinger et al. 2016; Zhao et al. 2016; Matheny et al. 2006; Larsson 2007) and to assess the similarities between the cloned sequences (Additional file 1; Additional file 2).

A reduced version of the previous dataset with only one sequence from each cloned sample was created. After removing near-identical sequences with no phylogenetic resolution, the final dataset comprised 119 sequences, including 32 sequences from GenBank and four sequences of Stephanospora as outgroups, and was divided into five partitions for further analyses: ITS1, 5.8S, ITS2, LSU and RPB2. Each partition was aligned separately with MAFFT v7.311 (Katoh and Standley 2013) using the E-INS-i algorithm for ITS1 and ITS2, and L-INS-i for 5.8S, LSU and RPB2. The alignments were examined and corrected manually in AliView v1.5 (Larsson 2014) and trimmed to remove uneven ends. Following the simple indel coding (Simmons and Ochoterena 2000), a morphological matrix were constructed using SeqState (Müller 2005) where indels were coded as binary characters. The nucleotide alignments were then trimmed with trimAl v1.4.rev22 (Capella-Gutiérrez et al. 2009) with the option -gappyout to remove unaligned regions.

Maximum-likelihood tree reconstruction was performed with IQ-TREE v1.6.7.1 (Nguyen et al. 2015). The best-fit evolutionary models and partitioning scheme for this analysis were estimated by the built-in ModelFinder (option -m MF +
MERGE) allowing the partitions to share the same set of branch lengths but with their own evolution rate (-spp option) (Chernomor et al. 2016; Kalyaanamoorthy et al. 2017). Branch support was assessed with 1000 replicates of ultrafast bootstrapping (UFBoot) (Hoang et al. 2018) and allowing resampling partitions and then sites within these partitions to reduce the likelihood of false positives on branch support (option -bspec GENESITE).

Bayesian Inference (BI) was implemented using MRBAYES v3.2 (Ronquist et al. 2012) with two independent runs, each one with four chains and starting from random trees. The best-fit evolutionary models and partitioning scheme for these analyses were estimated as for the ML analysis but restricting the search to models implemented on MRBAYES (options -m TESTMERGEONLY -mset mrbayes). Chains were run for $10^{7}$ generations with tree sampling every 1000 generations. The burn-in was set to $25 \%$ and the remaining trees were used to calculate a $50 \%$ majority consensus tree and Bayesian Posterior Probability (BPP). The convergence of the runs was assessed on TRACER v1.7 (Rambaut et al. 2018) to ensure the potential scale reduction factors (PSRF) neared 1.0 and the effective sample size values (ESS) were sufficiently large ( $>200$ ). Nodes with BPP $\geq 0.95$ and/or UFBoot $\geq 95$ were considered strongly supported. Alignment and phylogenetic trees are deposited in Treebase (ID: 24428).

\section{RESULTS}

From this section, all taxa are referred to by the names proposed in this study.

\section{Field data}

Fieldwork resulted in the discovery of approximately 100 new specimens, now placed within Pterulaceae (Table 2). Axenic culture isolation was also possible from several of these specimens.

\section{Phylogenetic analyses}

A total of 278 sequences from 123 samples were generated in this study: 153 nrITS, 74 nrLSU and 51 RPB2; 61 from cloning and 40 from genome mining. The final alignment 


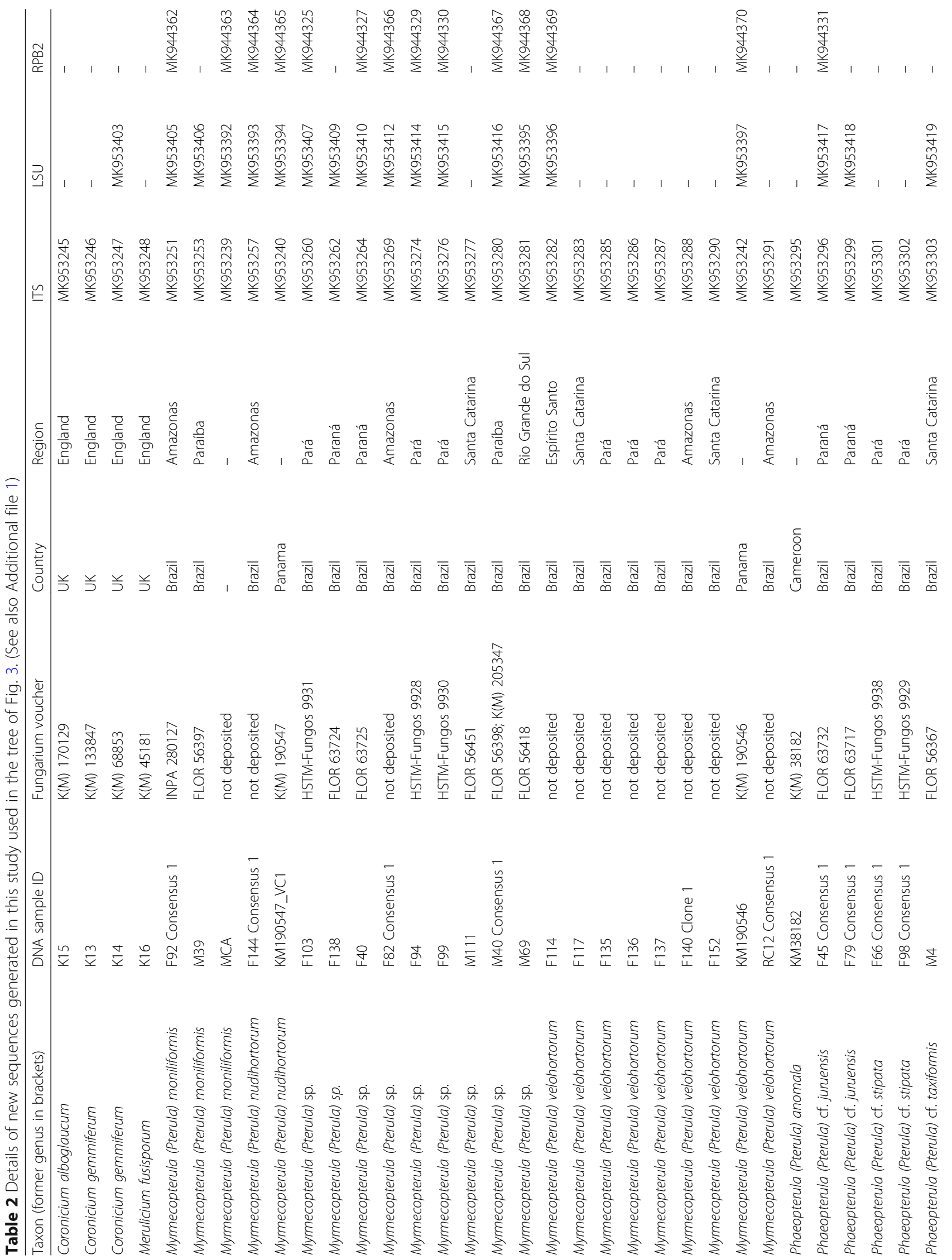




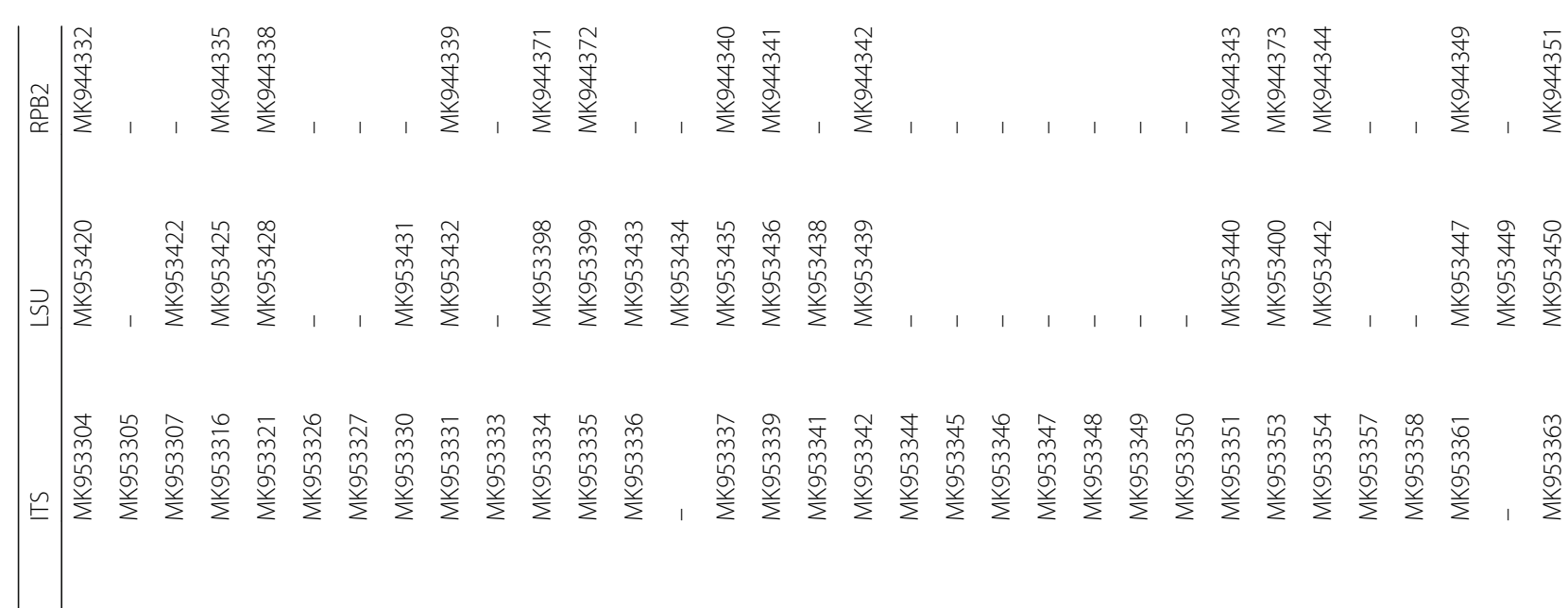

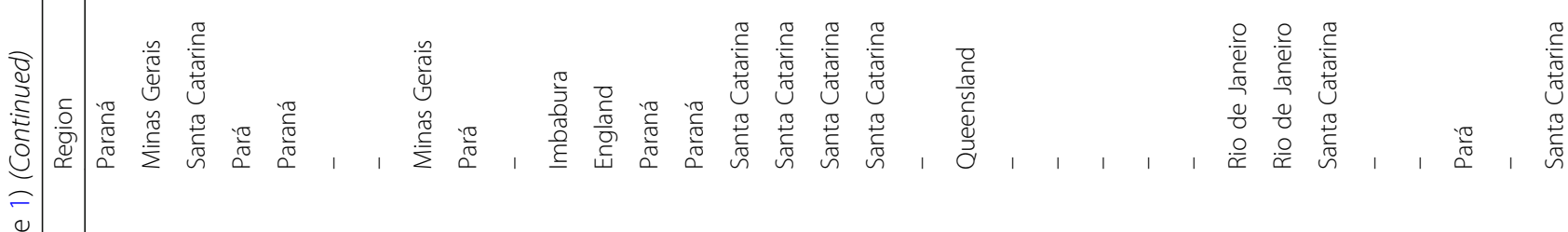

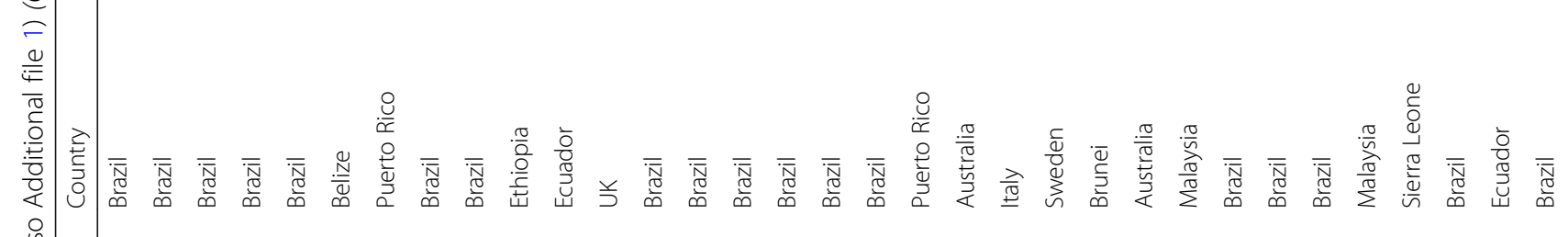

$\frac{n}{\pi}$

ming

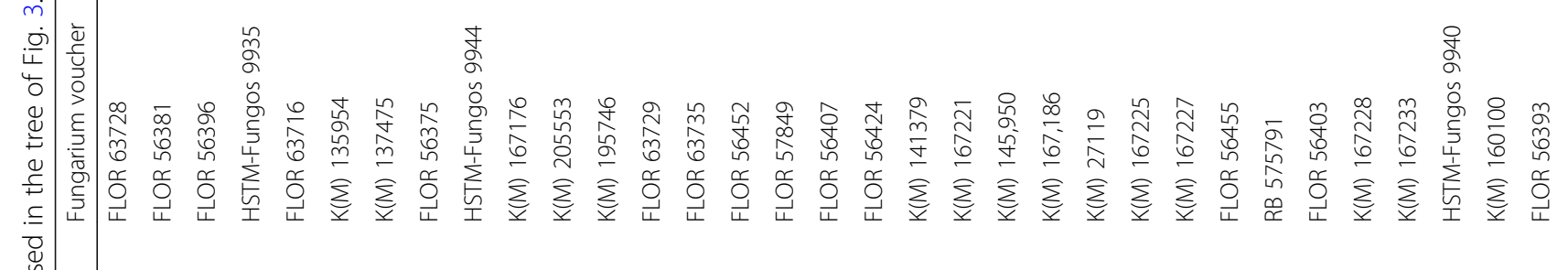

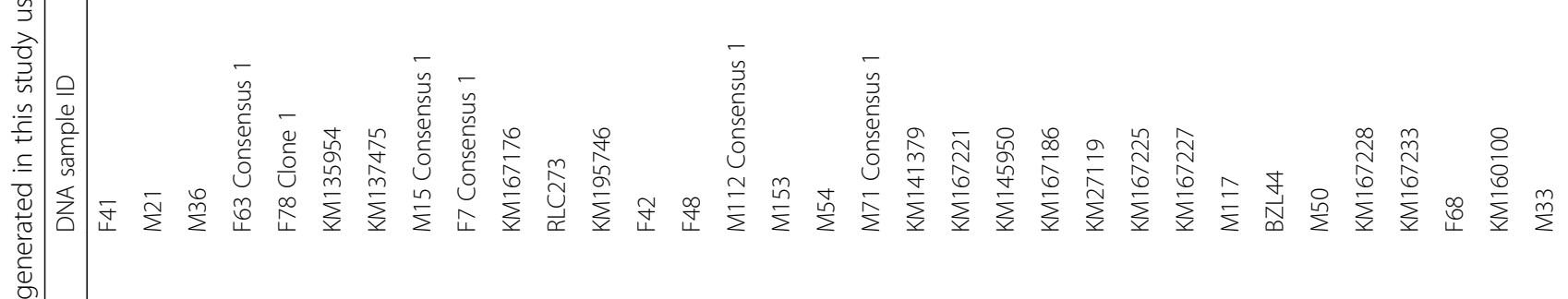

$\frac{\bar{Q}}{\overrightarrow{0}}$

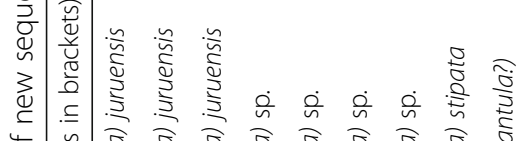

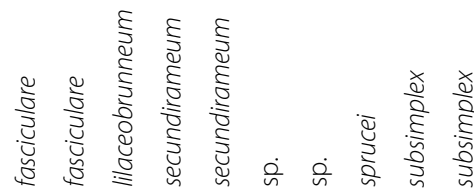

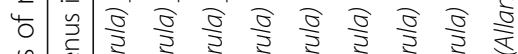

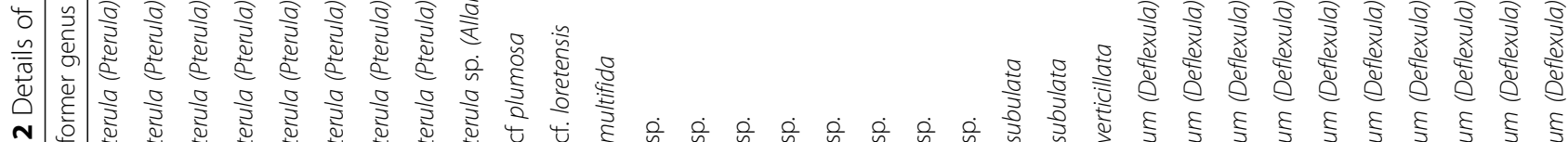

党

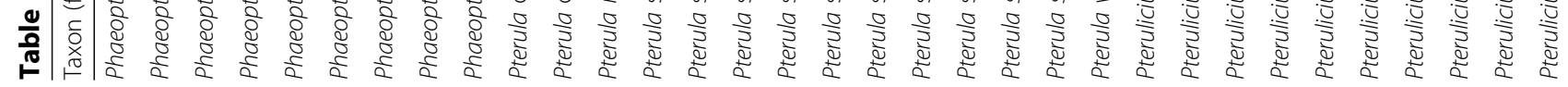




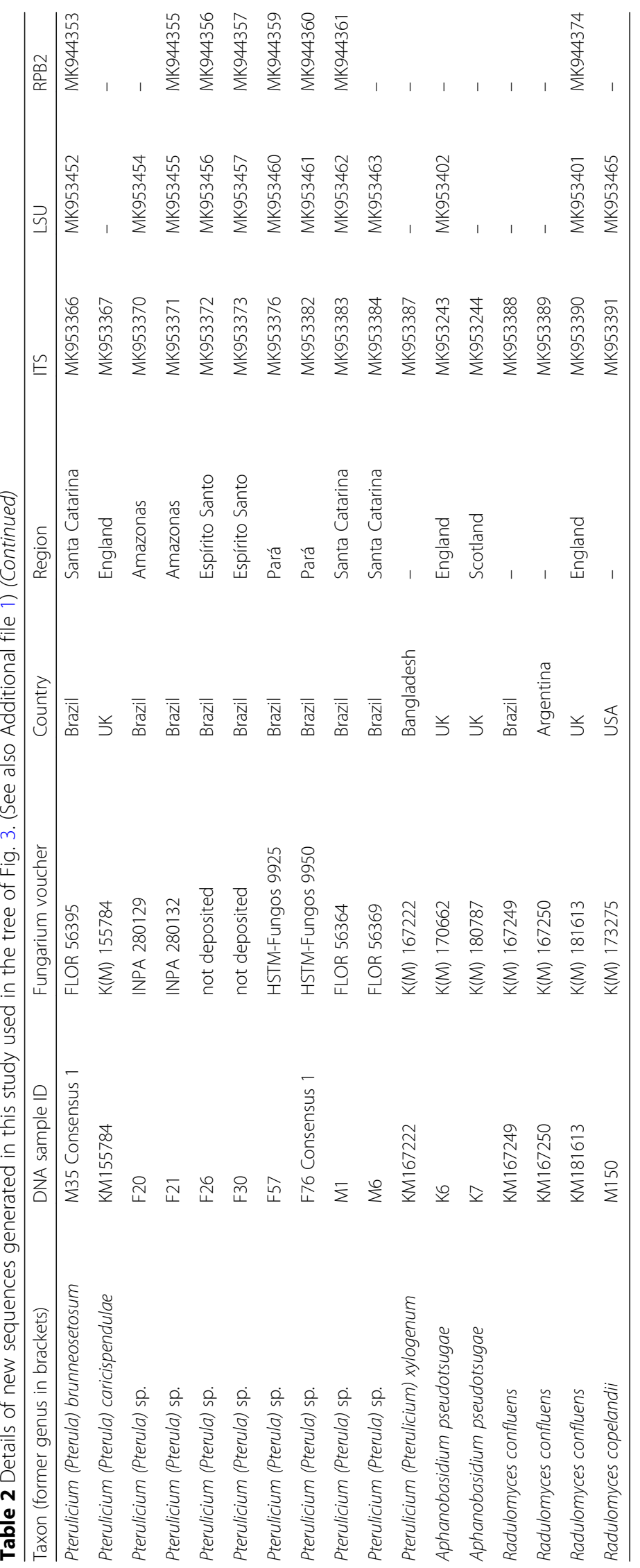


consisted of 113 sequences with 2737 characters and 1050 parsimony-informative sites. The BI analysis converged both runs as indicated by the effective sample sizes (ESS) of all parameters above 2800 and the potential scale reduction factors (PSRF) equal 1.000 for all the parameters according to the 95\% HPD Interval.

The new classification proposed in this study (Fig. 3), highlights six main clades containing nine genera: Radulomycetaceae (containing Aphanobasidium, Radulotubus and Radulomyces), Phaeopterula (hereinafter abbreviated as Ph.; previously Pterula spp.), Coronicium superclade (grouping Merulicium and Coronicium), Pterulicium (previously Pterulicium, Pterula spp. and Deflexula spp.), Pterula and Myrmecopterula (Myrmecopterula gen. nov., previously Pterula spp.).

\section{Radulomycetaceae $(U F B o o t=99 ; B P P=1)$}

This clade groups with strong support three of the five resupinate genera recognized in Pterulaceae, namely Aphanobasidium (UFBoot $=100 ; B P P=1$ ), Radulotubus (UFBoot $=100 ; B P P=1)$ and Radulomyces (UFBoot $=$ 100; $B P P=0.86$ ). The placement of Aphanobasidium and Radulomyces into Pterulaceae was previously shown by phylogenetic reconstructions of corticioid taxa (Larsson et al. 2004; Larsson 2007). Radulotubus was proposed by Zhao et al. (2016) as sister clade of Radulomyces to accommodate one species bearing poroid hymenophore. In our analyses, Radulotubus was recovered in the same position as in the original publication. This is the only poroid species within Pterulaceae.

No members of the three genera within this superclade are pteruloid (i.e. coralloid basidiomes with dimitic hyphal system) in their morphology and consequently we introduce the family name Radulomycetaceae fam. nov. to accommodate them, as discussed further below. The current sister clade to Pterulaceae in our analyses is Stephanosporaceae, from which members of the Radulomycetaceae clade are clearly distinct phylogenetically and morphologically.

\section{Phaeopterula (UFBoot $=100 ; B P P=1)$}

Phaeopterula received maximum support in both analyses. It includes Pterula stipata, Pt. anomala, Pt. juruensis and other species which all have dark brown basidiomes. This clade is the first coralloid lineage to diverge within Pterulaceae. As these species render Pterula paraphyletic, a reclassification is needed. The generic name Phaeopterula was originally proposed as a subgenus of Pterula to accommodate Ph. hirsuta and Ph. juruensis (Hennings 1900; Hennings 1904). We propose its reintroduction below to distinguish these brownpigmented taxa from Pterula s. str.
Coronicium superclade (UFBoot $=98 ; B P P=1)$

This clade groups the remaining two resupinate genera of Pterulaceae, the monospecific Merulicium and Coronicium (UFBoot $=100 ; B P P=1)$. Both genera form resupinate basidiomes but differ in the hyphal system present (dimitic in Merulicium, monomitic in Coronicium). Some Pterulicium species also show transitions in their morphology to a resupinate state. Corner (1950) showed that Pm. xylogenum Corner could form monomitic corticioid patches independent of the coralloid state and even in its absence, thus appearing to be truly corticioid. Furthermore, experimental studies on Pm. echo show a dimitic, resupinate, fertile corticioid phase both on agar and when cultured on cocoa twigs (McLaughlin and McLaughlin 1972; McLaughlin et al. 1978; McLaughlin and McLaughlin 1980). Despite the morphological distinctiveness from the rest of Pterulaceae, there is a trend in the morphology and strong phylogeny support for the placement of the Coronicium superclade among Pterula/Myrmecopterula and Pterulicium clades within Pterulaceae.

\section{Pterulicium (UFBoot $=99 ; B P P=1)$}

Two type species, Pterulicium xylogenum and Deflexula fascicularis, are nested within this clade alongside several species currently assigned to Pterula but which all have simple basidiomes (unbranched or limited branching). The Pterula species are interspersed with some Deflexula, rendering both genera polyphyletic. Pterulicium xylogenum forms a wellsupported subclade with Pterula secundiramea (=Pt. palmicola). Deflexula fascicularis forms a subclade with other Deflexula species that share globose spores, an unusual feature within Pterulaceae, most of which form ellipsoid to subamygdaliform spores.

\section{Pterula (UFBoot $=100 ; B P P=1)$}

This clade groups the true Pterula spp. that are represented by very bushy coralloid basidiomes, usually robust and taller than those of Pterulicium, stipe concolorous with hymenophore and lacking a cottony subiculum. Pterula has a mainly pantropical and pansubtropical distribution, with occurrence reported to all continents except Antarctica (Corner 1970).

\section{Myrmecopterula (UFBoot $=97 ; B P P=1)$}

This sister clade of Pterula represents the newly proposed genus (see below). It groups the two species cultivated by attine ants in the Apterostigma pilosum group with $M$. moniliformis and several unidentified free-living species. The species in this clade are only known from the Neotropics. Myrmecopterula is divided into seven subclades (Fig. 3) representing the two mutualists (MUTV and MUTN), three closely related to M. velohortorum (SAPV 1-3) and two closely related to $M$. nudihortorum (SAPN 1-2). 


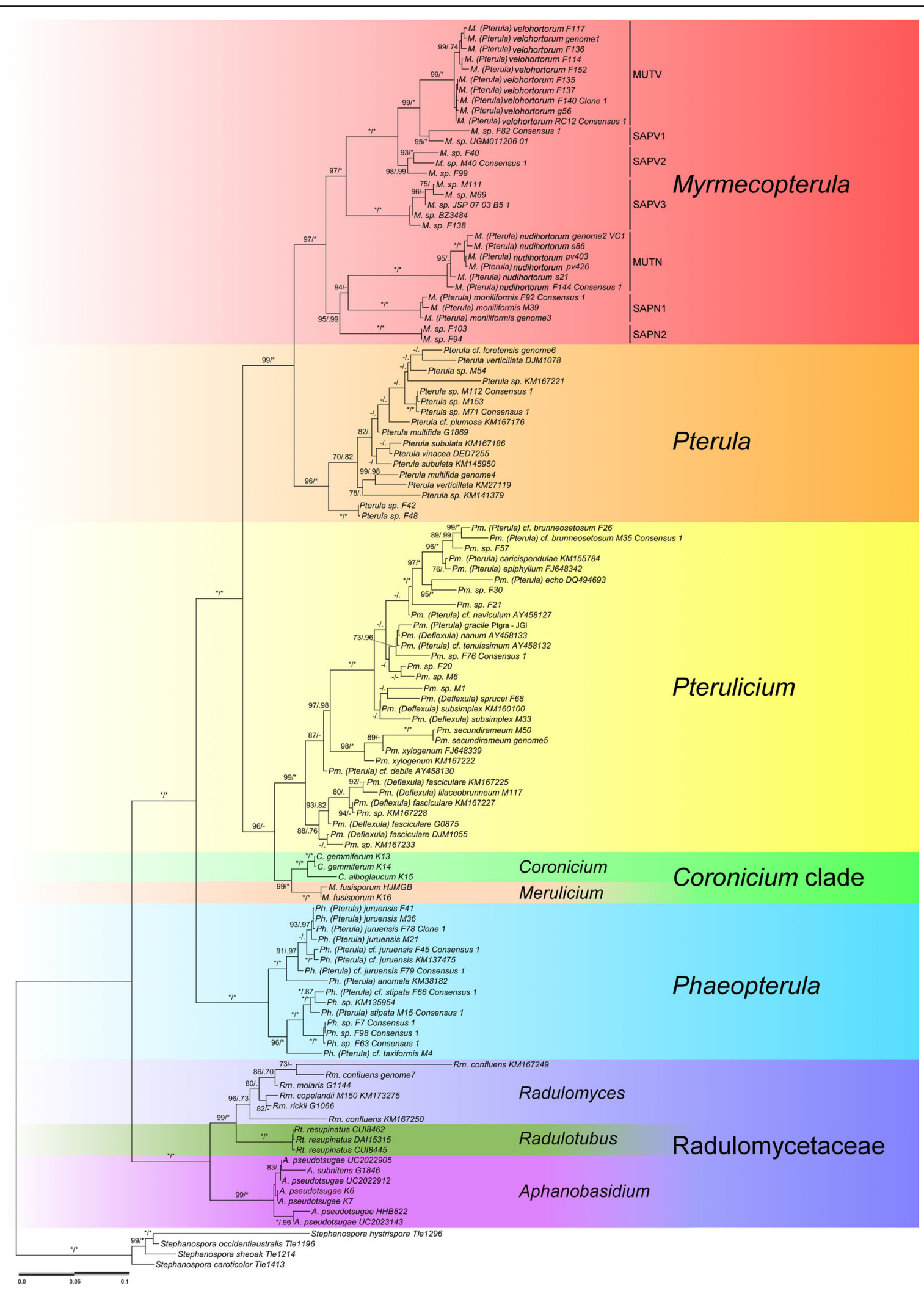

Fig. 3 (See legend on next page.) 
(See figure on previous page.)

Fig. 3 Maximum-likelihood tree of Pterulaceae and Radulomycetaceae. Support values on the branches are UFBoot/BPP and shown only for UFBoot $\geq 70$ and BPP $\geq 0.70$ and branch length $\geq 0.003$ substitutions per site. Asterisks $\left(^{*}\right)$ represent maximum UFBoot/BPP values, dashes (-) represent values below the cut-off threshold (70\%), and dots (.) represent ML clades that were not recovered in the Bl tree. Details for the complete tree can be found in Additional file 2 and TreeBase (ID: 24428). Scale bar: nucleotide substitutions per site

\section{TAXONOMY}

Radulomycetaceae Leal-Dutra, Dentinger, G.W. Griff., fam. nov.

\section{MycoBank MB831047.}

Diagnosis: Differs from resupinate forms of Pterulaceae in the monomitic hyphal system and the absence of cystidia. Cystidia may be either present or absent in Pm. xylogenum, in the latter case the amygdaliform spores differentiate the species from Radulomyces that has ellipsoid to globose spores.

Etymology: From the type genus Radulomyces.

Type genus: Radulomyces M.P. Christ. 1960.

Description: Basidiome resupinate, effused, mostly adnate, ceraceous, hymenophore smooth, tuberculate, odontioid, raduloid or poroid. Hyphal system monomitic, generative hyphae with clamps, hyaline, thin- to slightly thick-walled. Cystidia absent. Basidia terminal clavate or other form if pleural, usually with 4-sterigmata and a basal clamp. Basidiospores ellipsoid to globose, hyaline, mostly smooth, thin- to slightly thick-walled, acyanophilous, inamyloid and non-dextrinoid.

Notes: Radulomyces, Aphanobasidium and Radulotubus are placed in Radulomycetaceae. Larsson (2007) suggested that Lepidomyces had affinities to Aphanobasidium and could possibly be placed in Pterulaceae. However, no sequence data for the genus are available. Lepidomyces is described as bearing pleurobasidia as in Aphanobasidium, but also leptocystidia as in Coronicium and Merulicium. Given its morphological similarities to Aphanobasidium and the Coronicium superclade, we retain Lepidomyces as incertae sedis until molecular data are available to confirm its phylogenetic position

Myrmecopterula Leal-Dutra, Dentinger \& G.W. Griff., gen. nov.

MycoBank MB831048.

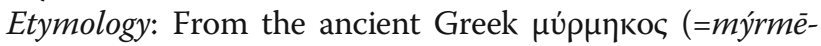
$k o s)$, genitive form of $\mu$ úp $\mu \eta \xi$ (=mýrmēx), ants. Thus,
Pterula of the ants, due to the observed relationship of several taxa in this genus with nests of fungus-growing ants.

Diagnosis: Differs from Pterula in the presence of the cottony subiculum.

Type species: Myrmecopterula moniliformis (Henn.) LealDutra et al. 2019.

Description: Basidiome if present bushy, pteruloid, white-cream to light brown and greyish surface, normally concolorous or stipe with a darker tone than the hymenophore, arising from cottony subiculum with mycelial cords. Stipe surface sterile. Hyphal system, dimitic hyphal system. Basidiospores relatively small spores, usually less than $7 \mu \mathrm{m}$ wide.

Ecology: Usually associated with the nests of ants, growing on top, or from a living or dead nest, or being cultivated by the ants.

Notes: Basidiomes of Myrmecopterula species are very similar to those of Pterula in habit, shape, and colour, but differ in the presence of mycelial cords and a cottony subiculum from which the basidiomes emerge. Some species of Myrmecopterula arise from soil, while others superficially appear to grow on wood. Closer observation of basidiomes formed on wood revealed that, rather than being lignicolous, they instead grow from a loose, granular substrate within a cavity inside the wood. This substrate in some cases resembles the substrate in the fungus gardens of the Apterostigma pilosum group of ants. In addition, M. moniliformis, which arises from soil, has been found emerging from active and inactive attine nests, (S. Sourell, pers. comm.; M. C. Aime, pers. comm.). Thus, all but one of the Myrmecopterula clades found to date had some association with attine ants, of which the two farmed mutualist species (M. nudihortorum and $M$. velohortorum) are best known. The five other species (of which only $M$. moniliformis is named) are less well studied and may play a role in decomposition of residual substrates in abandoned fungus garden, or potentially even as mycoparasites of the ant cultivar. In 
contrast, no Pterula spp. have any reported association with ants, but instead are found growing directly from wood and leaf litter.

Myrmecopterula moniliformis (Henn.) Leal-Dutra, Dentinger \& G.W. Griff., comb. nov.

MycoBank MB831049.

Basionym: Lachnocladium moniliforme Henn., Hedwigia 43: 198 (1904).

Synonyms: Pterula moniliformis (Henn.) Corner, Ann. Bot., Lond., n.s. 16: 569 (1952).

Thelephora clavarioides Torrend, Brotéria, sér. Bot. 12: 61 (1914).

Description: Corner (1952b: 546-548).

Myrmecopterula nudihortorum (Dentinger) Leal-Dutra, Dentinger \& G.W. Griff., comb. nov.

MycoBank MB831050.

Basionym: Pterula nudihortorum Dentinger, Index Fungorum 98: 1 (2014); as 'nudihortus', and later 'nudihorta'.

Diagnosis: In the field, recognized by the absence of any veil on the fungus garden in Apterostigma nests, usually inside decomposing trunks or underground. In culture, it forms very little aerial mycelium and exhibits very slow growth $(2-3 \mathrm{~mm} /$ week radial growth rate on PDA at 25C). Hyphal clamps abundant.

Notes: This species was formerly known as the ant cultivar G4. It is only known from the nest of fungusgrowing ants in the Apterostigma pilosum group in the A. manni subclade (Schultz 2007).

Myrmecopterula velohortorum (Dentinger) Leal-Dutra, Dentinger \& G.W. Griff., comb. nov.

MycoBank MB831051.

Basionym: Pterula velohortorum Dentinger. Index Fungorum 98: 1 (2014); as 'velohortus', and later 'velohorta'.

Diagnosis: In the field, recognized by the Apterostigma garden covered by a mycelial veil, usually inside decomposing trunks, below the leaf litter or hanging on exposed surfaces aboveground. In culture, it forms very cottony aerial mycelia with presence of racquet hyphae (Fig. 5 in Additional file 3). Large and abundant hyphal clamps. Slow growth rate, but faster than $M$. nudihortorum.

Notes: This species was formerly known as the ant cultivar G2. It is only known from the nest of fungus-growing ants in the Apterostigma pilosum group in the $A$. dentigerum subclade (Schultz 2007).

Phaeopterula (Henn.) Sacc. \& D. Sacc., Syll. Fung. 17: 201 (1905).

Basionym: Pterula subgen. Phaeopterula Henn., Monsunia 1: 9 (1900) [“1899”].

Type species: Phaeopterula hirsuta (Henn.) Sacc. \& D. Sacc. 1899.

Description: Basidiomes pteruloid, solitary or gregarious, scarcely branched to almost bushy, monopodial and slightly symmetric, branches from light brownish pink or greyish to pale brown and stipe dark reddish to rusty brown. Stipe surface glabrous with agglutinated hyphae (not sclerotioid) to villosetomentose. Dark brown mycelial cords usually present. Hyphal system dimitic with thick-walled skeletal hyphae, generative hyphae thin-walled and often clamped. Hymenial cystidia absent, caulocystidia sometimes present. Basidia terminal, clavate to suburniform. Basidiospores less than $9 \mu \mathrm{m}$ varying between pip-shaped, subamygdaliform and ellipsoid.

Ecology: Growing on dead twigs or dead wood.

Notes: Hennings (1900) recognized the subgenus Phaeopterula to accommodate Pterula hirsuta that was distinguished from other Pterula species by the reportedly brown spores. Hennings (1904) later described a second species in the subgenus, $P h$. juruensis, but noted that it was morphologically quite distinct from $\mathrm{Ph}$. hirsuta. Phaeopterula was raised to generic level by Saccardo and Saccardo (1905) who cited only Ph. juruensis. Pterula hirsuta was recombined in Dendrocladium by Lloyd (1919) but later returned to Pterula by Corner (1950), even though Corner did not confirm the presence of brown spores in the samples he examined. Although we also have not observed pigmented spores in any of these taxa, dark brown pigments in the stipe hyphae are a consistent and diagnostic feature in this group, so we resurrect the name Phaeopterula. The term 'Phaeo-' relates to brown-pigmented basidiospores, but while members of this genus do 
not have brown basidiospores, they do contain brown hyphal pigments.

Phaeopterula anomala (P. Roberts) Leal-Dutra Dentinger, G.W. Griff., comb. nov.

MycoBank MB830999.

Basionym: Pterula anomala P. Roberts, Kew Bull. 54(3): 528 (1999).

Description: Roberts (1999: 528-529).

Phaeopterula hirsuta (Henn.) Sacc. \& D. Sacc., Syll. fung. (Abellini) 17: 201 (1905).

MycoBank MB469044.

Basionym: Pterula hirsuta Henn., Monsunia 1: 9 (1899) [1900].

Synonym: Dendrocladium hirsutum (Henn.) Lloyd, Mycol. Writ. 5: 870 (1919).

Description: Corner (1950: 517).

Phaeopterula juruensis Henn. ex Sacc. \& D. Sacc., Syll. Fung. 17: 201 (1905).

MycoBank MB634235.

Basionym: Phaeopterula juruensis Henn. ex Sacc. \& D. Sacc., Syll. Fung. 17: 201 (1905).

Synonym: Dendrocladium juruense (Henn. ex Sacc. \& D. Sacc.) Lloyd, Mycol. Writ. 5: 870 (1919).

Pterula juruensis (Henn. ex Sacc. \& D. Sacc.) Corner, Monogr. Clavaria.: 518 (1950).

Phaeopterula juruensis Henn., Hedwigia 43 (3): 175 (1904).

Descriptions: Corner (1950:518; 1952b: 542-544).

Phaeopterula stipata (Corner) Leal-Dutra, Dentinger, G.W. Griff., comb. nov.

MycoBank MB831000.

Basionym: Pterula stipata Corner, Ann. Bot., Lond., n.s. 16: 568 (1952).

Description: Corner (1952b: 556-557).
Phaeopterula taxiformis (Mont.) Leal-Dutra, Dentinger, G.W. Griff., comb. nov.

MycoBank MB831001.

Basionym: Pterula taxiformis Mont., Syll. Gen.: 181 (1856).

Synonyms: Lachnocladium taxiforme (Mont.) Sacc., Syll. Fung. 6: 740 (1888).

Pterula humilis Speg., Revista Argent. Hist. Nat. 1(2): 110 (1891).

Pterula humilis var. tucumanensis Speg., Anal. Mus. nac. B. Aires, Ser. 3 12: 280 (1909).

Descriptions: Corner (1950: 523-524; 1952b: 560-561).

Phaeopterula taxiformis var. gracilis (Corner) LealDutra, Dentinger, G.W. Griff., comb. nov.

MycoBank MB831002.

Basionym: Pterula taxiformis var. gracilis Corner, Ann. Bot., Lond., n.s. 16: 568 (1952).

Description: Corner (1952b: 561).

Pterulicium Corner, Monogr. Clavaria.: 699 (1950).

Synonym: Deflexula Corner, Monogr. Clavaria.: 695 (1950).

Type Species: Pterulicium xylogenum (Berk. \& Broome) Corner 1950.

Description: Basidiomes pteruloid rarely corticioid, solitary or gregarious, simple or scarcely branched, occasionally exhibiting abundant unilateral branching (Figs. 1i, 1), varying from creamy white to brown on the stipe and creamy white on the tips or creamy white or pale lilaceous to pale brown on uniformly coloured basidiomes. Stipe surface sometimes sclerotioid (see Corner 1950). Hyphal system dimitic with slightly thick-walled skeletal hyphae, generative hyphae thin-walled and often clamped. Hymenial cystidia usually present, caulocystidia sometimes present. Basidia terminal, clavate to suburniform. Basidiospores shape varying between globose to subglobose, pip-shaped, amygdaliform to subamygdaliform, ellipsoid.

Ecology: On dead leaves, dead twigs or dead wood, rarely as a pathogen or endophyte of living plants.

Notes: Deflexula is synonymised with Pterulicium in 
this study. In addition, several species previously placed in Pterula are transferred to Pterulicium below. Other Pterula species that might need to be recombined in Pterulicium, require further investigation since their original descriptions do not provide enough information to confidently assign them here.

Pterulicium argentinum (Speg.) Leal-Dutra, Dentinger, G.W. Griff., comb. nov.

MycoBank MB831003.

Basionym: Mucronella argentina Speg., Anal. Mus. nac. Hist. nat. B. Aires 6: 178 (1899) [“1898”].

Synonyms: Deflexula argentina (Speg.) Corner, Ann. Bot., Lond., n.s. 16: 276 (1952).

Deflexula lilaceobrunnea var. elongata Corner, Ann. Bot., Lond., n.s. 16: 276 (1952).

Descriptions: Corner (1952a: 276; 1970: 196).

Pterulicium argentinum var. ramosum (Corner) LealDutra, Dentinger, G.W. Griff., comb. nov.

MycoBank MB831004.

Basionym: Deflexula argentina (Speg.) Corner, Ann. Bot., Lond., n.s. 16: 276 (1952).

Description: Corner (1970: 197).

Pterulicium bambusae (Corner) Leal-Dutra, Dentinger, G.W. Griff., comb. nov.

MycoBank MB831005.

Basionym: Pterula bambusae Corner, Beih. Nova Hedwigia 33: 209 (1970).

Description: Corner (1970: 209).

Pterulicium bromeliphilum (Corner) Leal-Dutra, Dentinger, G.W. Griff., comb. nov.

MycoBank MB831006.

Basionym: Pterula bromeliphila Corner, Beih. Nova Hedwigia 33: 210 (1970)

Description: Corner (1970: 210).
Pterulicium brunneosetosum (Corner) Leal-Dutra, Dentinger, G.W. Griff., comb. nov.

MycoBank MB831007.

Basionym: Pterula brunneosetosa Corner, Ann. Bot., Lond., n.s. 16: 566 (1952).

Descriptions: Corner (1952b: 535-536; 1970: 210).

Pterulicium campoi (Speg.) Leal-Dutra, Dentinger, G.W. Griff., comb. nov.

MycoBank MB831008.

Basionym: Pterula campoi Speg., Bol. Acad. nac. Cienc. Córdoba 25: 29 (1921).

Descriptions: Corner (1970: 210-211) and Spegazzini (1921: 29-30).

Pterulicium caricis-pendulae (Corner) Leal-Dutra, Dentinger, G.W. Griff., comb. nov.

MycoBank MB831009.

Basionym: Pterula caricis-pendulae Corner, Beih. Nova Hedwigia 33: 211 (1970).

Description: Corner (1970: 211-212).

Pterulicium crassisporum (P. Roberts) Leal-Dutra, Dentinger, G.W. Griff., comb. nov.

MycoBank MB831010.

Basionym: Pterula crassispora P. Roberts, Kew Bull. 54: 531 (1999).

Description: Roberts (1999: 531-532).

Pterulicium cystidiatum (Corner) Leal-Dutra, Dentinger, G.W. Griff., comb. nov.

MycoBank MB831011.

Basionym: Pterula cystidiata Corner, Ann. Bot., Lond., n.s. 16: 567 (1952).

Description: Corner (1952b: 537-539).

Pterulicium debile (Corner) Leal-Dutra, Dentinger, G.W. Griff., comb. nov.

MycoBank MB831012. 
Basionym: Pterula bromeliphila Corner, Monogr. Clavaria.: 698 (1950).

Description: Corner (1950: 508-510).

Pterulicium echo (D.J. McLaughlin \& E.G. McLaughlin) Leal-Dutra, Dentinger, G.W. Griff., comb. nov.

MycoBank MB831013.

Basionym: Pterula echo D.J. McLaughlin \& E.G. McLaughlin, Can. J. Bot. 58: 1328 (1980).

Description: McLaughlin and McLaughlin (1980: 13281332).

Pterulicium epiphylloides (Corner) Leal-Dutra, Dentinger, G.W. Griff., comb. nov.

MycoBank MB831014.

Basionym: Pterula epiphylloides Corner, Ann. Bot., Lond., n.s. 16: 567 (1952).

Description: Corner (1952b: 540).

Pterulicium epiphyllum (Corner) Leal-Dutra, Dentinger, G.W. Griff., comb. nov.

MycoBank MB831015.

Basionym: Pterula epiphylla Corner Monogr. Clavaria.: 698 (1950).

Description: Corner (1950: 510-511).

Pterulicium fasciculare (Bres. \& Pat.) Leal-Dutra, Dentinger, G.W. Griff., comb. nov.

MycoBank MB831016.

Basionym: Pterula fascicularis Bres. \& Pat., Mycol. Writ. 1: 50 (1901).

Synonym: Deflexula fascicularis (Bres. \& Pat.) Corner, Monogr. Clavaria.: 395 (1950).

Description: Corner (1950: 395-397).

Pterulicium fluminense (Corner) Leal-Dutra, Dentinger, G.W. Griff., comb. nov.

MycoBank MB831017.
Basionym: Pterula fluminensis Corner, Ann. Bot., Lond., n.s. 16: 567 (1952).

Descriptions: Corner (1952b: 541-542; 1970: 215).

Pterulicium gordium (Speg.) Leal-Dutra, Dentinger, G.W. Griff., comb. nov.

MycoBank MB831018.

Basionym: Clavaria gordius Speg., Anal. Soc. cient. Argent. 17(2): 83 (1884).

Synonym: Pterula gordius (Speg.) Corner, Monogr. Clavaria.: 513 (1950).

Description: Corner (1950: 513-514).

Pterulicium gordium var. macrosporum (Corner) Leal-Dutra, Dentinger, G.W. Griff., comb. nov.

MycoBank MB831019.

Basionym: Pterula gordius var. macrospora Corner, Proc. Linn. Soc. London 178: 100 (1967).

Description: Corner (1967: 100-101).

Pterulicium gracile (Desm. \& Berk.) Leal-Dutra, Dentinger, G.W. Griff., comb. nov.

MycoBank MB831020.

Basionym: Typhula gracilis Desm. \& Berk., Ann. nat. Hist., Mag. Zool. Bot. Geol. 1: 202 (1838).

Synonyms: Pistillaria gracilis (Desm. \& Berk.) Pat., Tab. analyt. Fung. (Paris)(6): 30 (1886).

Hirsutella gracilis (Desm. \& Berk.) Pat., Revue mycol., Toulouse 14(no. 54): 69 (1892).

Pterula gracilis (Desm. \& Berk.) Corner, Monogr. Clavaria.: 514 (1950).

Clavaria aculina Quél., C. r. Assoc. Franç. Avancem. Sci. 9: 670 (1881) [1880].

Pistillaria aculina (Quél.) Pat., Tab. analyt. Fung. (Paris)(6): 29 (Fig. 570) (1886).

Ceratella aculina (Quél.) Pat., Hyménomyc. Eur. (Paris): 157 (1887). 
Cnazonaria aculina (Quél.) Donk, Meded. Bot. Mus. Herb. Rijks Univ. Utrecht 9: 97 (1933).

Pistillaria aculina subsp. juncicola Bourdot \& Galzin, Hyménomyc. de France (Sceaux): 138 (1928) [1927].

Pistillaria aculina subsp. graminicola Bourdot \& Galzin, Hyménomyc. de France (Sceaux): 139 (1928) [1927].

Pistillaria aculina subsp. acicula Bourdot \& Galzin, Hyménomyc. de France (Sceaux): 139 (1928) [1927].

Typhula brunaudii Quél., C. r. Assoc. Franç. Avancem. Sci. 13: 283 (1885) [1884].

Clavaria brunaudii (Quél.) Sacc., Syll. fung. (Abellini) 6: 730 (1888).

Ceratella ferryi Quél. \& Fautrey, Revue mycol., Toulouse 15(no. 57): 15 (1893).

Pistillaria ferryi (Quél. \& Fautrey) Sacc., Syll. fung. (Abellini) 11: 141 (1895).

Pistillaria ferryi subsp. tremula Sacc., Syll. fung. (Abellini) 17: 202 (1905).

Mucronella rickii Oudem., Ned. kruidk. Archf, 3 sér. 2(3): 667 (1902).

Cnazonaria rickii (Oudem.) Donk, Meded. Bot. Mus. Herb. Rijks Univ. Utrecht 9: 99 (1933).

Ceratellopsis rickii (Oudem.) Corner, Monogr. Clavaria.: 205 (1950).

Description: Corner (1950: 514-516).

Pterulicium incarnatum (Pat.) Leal-Dutra, Dentinger, G.W. Griff., comb. nov.

MycoBank MB831021.

Basionym: Pterula incarnata Pat., in Patouillard \& Lagerheim, Bull. Herb. Boissier 3(1): 58 (1895).

Descriptions: Corner (1950: 517; 1970: 215-216).

Pterulicium intermedium (Dogma) Leal-Dutra, Dentinger, G.W. Griff,, comb. nov.

MycoBank MB831022.

Basionym: Pterula intermedia Dogma, Philipp. Agric. 49: 852 (1966).
Descriptions: Corner (1970): 216 and Dogma (1966: 852-855).

Pterulicium laxum (Pat.) Leal-Dutra, Dentinger, G.W. Griff., comb. nov.

MycoBank MB831023.

Basionym: Pterula laxa Pat., Bull. Soc. mycol. Fr. 18(2): 175 (1902).

Descriptions: Corner (1950: 518; 1970: 217).

Pterulicium lilaceobrunneum (Corner) Leal-Dutra, Dentinger, G.W. Griff., comb. nov.

MycoBank MB831024.

Basionym: Deflexula lilaceobrunnea Corner, Monogr. Clavaria.: 695 (1950).

Description: Corner (1950: 397-398).

Pterulicium lilaceobrunneum var. evolutius (Corner) Leal-Dutra, Dentinger, G.W. Griff., comb. nov.

MycoBank MB831025.

Basionym: Deflexula lilaceobrunnea var. evolutior Corner, Beih. Nova Hedwigia 33: 197 (1970).

Description: Corner (1970: 197-198).

Pterulicium longisporum (Corner) Leal-Dutra, Dentinger, G.W. Griff., comb. nov.

MycoBank MB831026.

Basionym: Pterula longispora Corner, Ann. Bot., Lond., n.s. 16: 567 (1952).

Description: Corner (1952b: 544-545).

Pterulicium macrosporum (Pat.) Leal-Dutra, Dentinger, G.W. Griff., comb. nov.

MycoBank MB831027.

Basionym: Ceratella macrospora Pat., in Patouillard \& Lagerheim, Bull. Soc. mycol. Fr. 8(3): 119 (1892).

Synonyms: Pistillaria macrospora (Pat.) Sacc., Syll. fung. (Abellini) 11: 142 (1895). 
Pterula macrospora (Pat.) Corner, Monogr. Clavaria.: 518 (1950).

Descriptions: Corner (1950: 518; 1970: 218).

Pterulicium majus (Corner) Leal-Dutra, Dentinger, G.W. Griff., comb. nov.

MycoBank MB831028.

Basionym: Deflexula major Corner, Ann. Bot., Lond., n.s. 16: 277 (1952).

Description: Corner (1952a: 277-278).

Pterulicium mangiforme (Corner) Leal-Dutra, Dentinger, G.W. Griff., comb. nov.

MycoBank MB831029.

Basionym: Deflexula mangiformis Corner, Ann. Bot., Lond., n.s. 16: 278 (1952).

Description: Corner (1952a: 278).

Pterulicium microsporum (Corner) Leal-Dutra, Dentinger, G.W. Griff., comb. nov.

MycoBank MB831030.

Basionym: Deflexula microspora Corner, Bull. Jard. bot. État Brux. 36: 264 (1966).

Description: Corner (1966: 264).

Pterulicium nanum (Pat.) Leal-Dutra, Dentinger, G.W. Griff., comb. nov.

MycoBank MB831031.

Basionym: Pterula nana Pat, Bull. Soc. mycol. Fr. 18(2): 175 (1902).

Synonyms: Deflexula nana (Pat.) Corner, Bull. Jard. bot. État Brux. 36: 264 (1966).

Pterula vanderystii Henn. [as 'vanderysti], Ann. Mus. Congo Belge, Bot., Sér. 5 2(2): 96 (1907).

Deflexula vanderystii (Henn.) Corner, Ann. Bot., Lond., n.s. 16: 284 (1952).

Description: Corner (1966: 264).

Pterulicium naviculum (Corner) Leal-Dutra, Dentinger, G.W. Griff., comb. nov.
MycoBank MB831032.

Basionym: Pterula navicula Corner, Ann. Bot., Lond., n.s. 16: 568 (1952).

Description: Corner (1952b: 549-550).

Pterulicium oryzae (Remsberg) Leal-Dutra, Dentinger, G.W. Griff., comb. nov.

MycoBank MB831033.

Basionym: Pistillaria oryzae Remsberg, Mycologia 32(5): 668 (1940).

Synonym: Pterula oryzae (Remsberg) Corner, Monogr. Clavaria.: 519 (1950).

Descriptions: Corner (1950: 519-520) and Remsberg (1940: 668-670).

Pterulicium phyllodicola (Corner) Leal-Dutra, Dentinger, G.W. Griff., comb. nov.

MycoBank MB831034.

Basionym: Pterula phyllodicola Corner, Beih. Nova Hedwigia 33: 220 (1970).

Description: Corner (1970: 220).

Pterulicium phyllophilum (McAlpine) Leal-Dutra, Dentinger, G.W. Griff., comb. nov.

MycoBank MB831035.

Basionym: Clavaria phyllophila McAlpine, Agric. Gaz. N.S.W., Sydney 7: 86 (1896).

Synonym: Pterula phyllophila (McAlpine) Corner, Monogr. Clavaria.: 520 (1950).

Description: Corner (1950: 520).

Pterulicium rigidum (Donk) Leal-Dutra, Dentinger, G.W. Griff., comb. nov.

MycoBank MB831036.

Basionym: Pterula rigida Donk, Monogr. Clavaria: 698 (1950).

Description: Corner (1950: 521). 
Pterulicium sclerotiicola (Berthier) Leal-Dutra, Dentinger, G.W. Griff., comb. nov.

MycoBank MB831037.

Basionym: Pterula sclerotiicola Berthier, Bull. trimest. Soc. mycol. Fr. 83: 731 (1968) [1967].

Description: Corner (1970: 221).

Pterulicium secundirameum (Lév) Leal-Dutra, Dentinger, G.W. Griff., comb. nov.

MycoBank MB831038.

Basionym: Clavaria secundiramea Lév., Annls Sci. Nat., Bot., sér. 3 2: 216 (1844).

Synonyms: Pterula secundiramea (Lév.) Speg., Bol. Acad. nac. Cienc. Córdoba 11(4): 466 (1889).

Deflexula secundiramea (Lév.) Corner, Beih. Nova Hedwigia 33: 199 (1970).

Pterula palmicola Corner, Ann. Bot., Lond., n.s. 16: 568 (1952).

Descriptions: Corner (1950: 521-522; 1952b: 555-556).

Notes: The synonymisation of Pm. palmicola (samples M50 and M83) in Pm. secundirameum (samples M70 and genome5) is based on our phylogenetic results and morphological comparisons. The only morphological difference between the two species is the shape of the basidiome, however, the other characters are similar and both species are nested together within our tree (Additional file 2).

Pterulicium sprucei (Mont.) Leal-Dutra, Dentinger, G.W. Griff., comb. nov.

MycoBank MB831039.

Basionym: Hydnum sprucei Mont., Syll. gen. sp. crypt. (Paris): 173 (1856).

Synonyms: Pterula sprucei (Mont.) Lloyd, Mycol. Writ. 5: 865 (1919).

Deflexula sprucei (Mont.) Maas Geest, Persoonia 3(2): 179 (1964).

Pterula pennata Henn., Hedwigia 43(3): 174 (1904).

Deflexula pennata (Henn.) Corner, Ann. Bot., Lond., n.s. 16: 278 (1952).
Descriptions: Corner (1952a: 278-279 as 'D. pennata'; 1970: 200-201) and Maas Geesteranus (1964: 178-179).

Pterulicium subsimplex (Henn.) Leal-Dutra, Dentinger, G.W. Griff., comb. nov.

MycoBank MB831040.

Basionym: Pterula subsimplex Henn., Hedwigia 36(4): 197 (1897).

Synonyms: Deflexula subsimplex (Henn.) Corner, Ann. Bot., Lond., n.s. 16: 279 (1952).

Pterula nivea Pat., Bull. Soc. mycol. Fr. 18(2): 174 (1902).

Deflexula nivea (Pat.) Corner, Monogr. Clavaria.: 398 (1950).

Mucronella pacifica Kobayasi, Bot. Mag., Tokyo 53: 160 (1939).

Deflexula pacifica (Kobayasi) Corner, Monogr. Clavaria.: 399 (1950).

Descriptions: Corner (1952a: 279-282; 1950: 399 as 'D. pacifica'.

Pterulicium subsimplex var. multifidum (Corner) Leal-Dutra, Dentinger, G.W. Griff., comb. nov.

MycoBank MB831041.

Basionym: Deflexula subsimplex var. multifida Corner, Ann. Bot., Lond., n.s. 16: 282 (1952).

Description: Corner (1952a: 282-283).

Pterulicium subtyphuloides (Corner) Leal-Dutra, Dentinger, G.W. Griff., comb. nov.

MycoBank MB831042.

Basionym: Pterula subtyphuloides Corner, Monogr. Clavaria.: 698 (1950).

Description: Corner (1950: 522-523).

Pterulicium sulcisporum (Corner) Leal-Dutra, Dentinger, G.W. Griff., comb. nov.

MycoBank MB831043.

Basionym: Deflexula sulcispora Corner, Ann. Bot., Lond., n.s. 16: 283 (1952).

Description: Corner (1952a: 283-284). 
Pterulicium tenuissimum (M.A. Curtis) Leal-Dutra, Dentinger, G.W. Griff., comb. nov.

MycoBank MB831044.

Basionym: Typhula tenuissima M.A. Curtis, Am. Journ. Art. Scienc. 6: 351 (1848).

Synonym: Pterula tenuissima (M.A. Curtis) Corner, MycoBank MB831045.

Monogr. Clavaria.: 524 (1950).

Description: Corner (1950: 524).

Pterulicium typhuloides (Corner) Leal-Dutra, Synonym: Deflexula ulmi (Peck) Corner, Monogr. ClaDentinger, G.W. Griff., comb. nov.

MycoBank MB832820.

Basionym: Pterula typhuloides Corner, Monogr. Clavaria.: 698 (1950).

Description: Corner (1950: 525-526).

Pterulicium typhuloides var. minor (Corner) LealDutra, Dentinger, G.W. Griff., comb. nov.

MycoBank MB832821.
Basionym: Pterula typhuloides var. minus Corner, Monogr. Clavaria.: 699 (1950).

Description: Corner (1950: 526-527).

Pterulicium ulmi (Peck) Leal-Dutra, Dentinger, G.W. Griff., comb. nov.

Basionym: Mucronella ulmi Peck, Ann. Rep. Reg. N.Y. St. Mus. 54: 154 (1902) [1901].

varia.: 400 (1950).

Descriptions: Corner (1950: 400; 1970: 202).

Pterulicium velutipes (Corner) Leal-Dutra, Dentinger, G.W. Griff., comb. nov.

MycoBank MB831046.

Basionym: Pterula velutipes Corner, Ann. Bot., Lond., n.s. 16: 569 (1952).

Description: Corner (1952b: 565-566).

Key to genera of Pterulaceae and Radulomycetaceae

\begin{tabular}{|c|c|c|}
\hline \multirow[t]{2}{*}{1} & Cultivated by ants of the Apterostigma pilosum group & Myrmecopterula* \\
\hline & Not cultivated by ants & 2 \\
\hline \multirow[t]{2}{*}{$2(1)$} & Basidiomes resupinate to effused & 3 \\
\hline & Basidiomes coralloid, thread like or allantoid** & 10 \\
\hline \multirow[t]{2}{*}{$3(2)$} & Hymenophore surface poroid & Radulotubus \\
\hline & Hymenophore surface smooth, tuberculate, odontioid to raduloid or merulioid & 4 \\
\hline \multirow[t]{2}{*}{$4(3)$} & Cystidia present & 5 \\
\hline & Cystidia absent & 8 \\
\hline \multirow[t]{2}{*}{$5(4)$} & Hyphal system monomitic & 6 \\
\hline & Hyphal system dimitic & 7 \\
\hline \multirow[t]{2}{*}{$6(5)$} & Spores ellipsoid to navicular, thin-walled, cystidia with incrustation & Coronicium \\
\hline & Spores amygdaliform, slightly thick-walled, cystidia smooth & Pterulicium xylogenum ${ }^{* * *}$ \\
\hline \multirow[t]{2}{*}{$7(5)$} & Hymenophore surface merulioid, presence of cystidia with resinous excretion & Merulicium \\
\hline & Hymenophore surface smooth, cystidia smooth & Pterulicium echo ${ }^{* * *}$ \\
\hline \multirow[t]{2}{*}{$8(4)$} & Basidia formed laterally from generative hyphae (pleural) & Aphanobasidium \\
\hline & Basidia formed at the end of generative hyphae (terminal) & 9 \\
\hline \multirow[t]{2}{*}{$9(8)$} & Spores ellipsoid to globose & Radulomyces \\
\hline & Spores amygdaliform & Pterulicium xylogenum ${ }^{* * *}$ \\
\hline $10(2)$ & Basidiome allantoid with swollen fertile regions intercalating with mycelial chords & Allantula \\
\hline
\end{tabular}




\begin{tabular}{|c|c|c|}
\hline & Basidiome coralloid or thread like & 11 \\
\hline \multirow[t]{2}{*}{$11(10)$} & Stipe and base of branches very dark brown fading towards the tips & Phaeopterula \\
\hline & Basidiomes concolourous or only the stipe light brown coloured & 12 \\
\hline \multirow[t]{2}{*}{$12(11)$} & Basidiomes simple or scarcely branched, growing up- or downwards & Pterulicium \\
\hline & Basidiomes densely ramified, always ageotropic & 13 \\
\hline \multirow[t]{2}{*}{$13(12)$} & Cottony subiculum present, associated with attine ants & Myrmecopterula \\
\hline & Cottony subiculum absent, without association with attine ants & Pterula \\
\hline
\end{tabular}

* Myrmecopterula cultivated by Apterostigma was never reported forming basidiomes

** Allantoid = sausage-shaped, in this case with inflated portions of hymenium intercalating with rhizomorph (see Allantula in Corner 1952c)

*** Pterulicium xylogenum and Pm. echo can have corticioid growth independently of coralloid basidiomes. The cystidia in the former may be either present or absent

\section{DISCUSSION}

\section{Introduction of Radulomycetaceae}

We consider that it is better to erect a new family for these three genera (i.e. Radulomyces, Radulotubus and Aphanobasidium) than to leave them in Pterulaceae where they are clearly phylogenetically and morphologically distinct from nearly all the other members of Pterulaceae. In contrast, Merulicium (Fig. 2b-c) and Coronicium (Fig. 2a) form corticioid basidiomes but our phylogenetic analyses place them clearly within Pterulaceae. Two Pterulicium species, Pm. echo and Pm. xylogenum, also form both pteruloid and corticioid basidiomes, either independently or together (McLaughlin and McLaughlin 1980; Corner 1950).

Whilst the corticioid basidiomes of Merulicium and Pm. echo contain a dimitic hyphal system, typical of Pterulaceae, those of Coronicium spp. and Pterulicium xylogenum form a monomitic hyphal system, like all members of Radulomycetaceae. However, no members of Radulomycetaceae form cystidia, whereas these cells are found in most Pterulaceae (Corner 1950, 1952a, 1952b, 1967, 1970; McLaughlin and McLaughlin 1980; Bernicchia and Gorjón 2010), including Coronicium spp. Thus, Radulomycetaceae is morphologically characterized by the combination of resupinate basidiomes, monomitic hyphal system and lack of cystidia. Moreover, our phylogenetic analyses strongly support the segregation of Radulomycetaceae from Pterulaceae.

\section{Reintroduction of Phaeopterula}

Phaeopterula spp. are distinct from other pterulaceous genera due to the distinctive brown colour of the main axis of the basidiome and monopodial/symmetric branching of these structures. This contrasts with other Pterulaceae which are either highly branched (bushy) and of uniform colour (Pterula and Myrmecopterula) or pigmented only at the stipe base, and (mostly) unbranched (Pterulicium). Hennings (1900) originally defined Phaeopterula by its brown spores. Corner (1950) cast doubt on the significance of this trait, but our results show that, despite an apparently misguided justification, Hennings was correct to group Ph. juruensis with Ph. hirsuta.

All Phaeopterula spp. are exclusively found on decaying wood, whereas members of other genera of Pterulaceae inhabit more diverse lignocellulosic substrates. Given the basal position of Phaeopterula in Pterulaceae, and the fact that all members of the sister family Radulomycetaceae are also lignicolous on wood, this habit is parsimoniously the ancestral condition. The reintroduction of Phaeopterula aims to pay tribute to Paul Hennings' work and his contribution to the taxonomy of Pterulaceae.

\section{Synonymy of Deflexula with Pterulicium}

Besides the paraphyly represented by Phaeopterula, the Pterulicium clade shows polyphyly of Pterula and Deflexula. Several species in the two latter genera are intermixed in a strongly supported subclade (Fig. 3). The presence of the type species of both Deflexula and Pterulicium within this clade requires that only one name be kept. Both genera were proposed by Corner (1950), to accommodate the dimitic and coralloid (but non-bushy) species, not fitting the description of Pterula. The name Pterulicium was based on a 'portmanteau' combination of Pterula and Corticium to reflect the presence of a corticioid patch at the stipe base (Corner 1950). However, this patch has only been reported in two species, Pterulicium xylogenum (Corner 1950) and Pm. echo (McLaughlin and McLaughlin 1980). Deflexula was named for the downward-oriented (positively geotropic) basidiomes (Corner 1950). Corner (1950) stated that the resupinate patch in Pterulicium xylogenum is monomitic, can exist independently of the coralloid basidiome and is fertile when facing downward; he suggested that there was a 
close similarity between Deflexula and Pterulicium in the way the resupinate patch develops from the base of the basidiome. He also made a case for the formation of a fertile hymenium when facing downward in the two genera as supporting this similarity. Nonetheless, experimental studies on Pm. echo show that orientation of the hymenium does not affect the ability to produce spores, i.e., the hymenium is ageotropic (McLaughlin et al. 1978) and raised doubts about the validity of the genus Deflexula. This morphological distinction is not supported by phylogenetic analysis (Dentinger et al. 2009, Fig. 3) and its emphasis through taxonomic preservation would perpetuate misunderstanding. Accordingly, we propose to retain Pterulicium for this clade to avoid major misinterpretations of the species morphology.

\section{Introduction of Myrmecopterula gen. nov.}

Two species of Pterulaceae are cultivated by fungusfarming ants of the Apterostigma pilosum group in South and Central America (Dentinger et al. 2009; Munkacsi et al. 2004; Villesen et al. 2004; Mueller et al. 2018). Despite intensive investigation, neither has been observed to form basidiomes, but $M$. velohortorum is characterised by the formation of a veil of mycelium around the fungus garden, whilst $M$. nudihortorum lacks this veil. We recovered both species in a strongly supported clade, as a sister clade of Pterula, alongside five other subclades containing fertile, apparently free-living species.

All the samples in this clade were collected from neotropical habitats (Fig. 1a-f), mostly as part of our recent fieldwork. During sampling campaigns by ourselves and others, it was observed that many of the 'free-living' specimens were associated in some way with living ant colonies or abandoned attine nests. Two Myrmecopterula samples belonging to subclade SAPV1 (CALD170307-02 and CALD170307-03; Fig. 1a) were found forming basidiomes atop two distinct but adjacent (1 m apart) living Apterostigma nests in Amazonian Rainforest. The cultivated mutualists from both nests were also analysed and found to belong to $M$. velohortorum confirming that the basidiomes were not linked to the cultivated mycelia in these nests. The third member of subclade SAPV1 was also reported forming a nascent basidiome on a living Apterostigma nest in Panama (Munkacsi et al. 2004). M. moniliformis (SAPN1; Fig. 1e) has been reported to be found outside both active and apparently inactive (see Myrmecopterula: Notes on Taxonomy section above) attine nests (S. Sourell, pers. comm.; M.C. Aime, pers.comm.) as was CALD170315-04 (SAPV2; Fig. 1b) and CALD170122-04 (SAPV3; Fig. 1c). Lastly, the mycelium of one sample (JSP 07-03 B 5.1; SAPV3) was isolated from a living Atta capiguara nest by Pereira et al. (2016).

The observations above and the phylogenetic analyses suggests that association with attine ants is a widespread trait amongst members of this clade, hence its naming as Myrmecopterula.

Most recent attention on Pterulaceae has been lavished on the ant-cultivated mutualists $M$. nudihortorum and $M$. velohortorum. These were once thought to be sister clades (Munkacsi et al. 2004; Villesen et al. 2004) but are now known to be only distantly related within the Myrmecopterula clade (Dentinger et al. 2009, Fig. 3). This suggests two possibilities for the evolution of the MyrmecopterulaApterostigma mutualism: (1) that it evolved independently on two occasions, or (2) that it is an ancestral condition of all Myrmecopterula. However, it is at present unclear whether the extant mutualistic association found for $M$. nudihortorum and $M$. velohortorum is ancestral, implying that the other taxa escaped the mutualism, or whether the looser association with ant nests widespread amongst members of Myrmecopterula was more recently elevated to a higher level of interdependence for these two species, as suggested by Dentinger et al. (2009). It is also possible that the free-living species within the Myrmecopterula may be specialised parasites specifically targeting their sister species that have formed a mutualism with the ants. An analogous situation is found in the leaf-cutting ants species Acromyrmex echinatior and its sister species Acromyrmex insinuator, the latter a highly specialised social parasite of the former (Sumner et al. 2004).

The basis of the association of 'free-living' species with attine ants and/or their abandoned nests is unclear. Given the apparent preference of some for abandoned nests, they may be specialised early stage colonisers of ant nest debris. A further possibility is that they are cheaters, deriving nutrition from the ant-collected biomass but not reciprocating by producing hyphae palatable to ants. This would represent a novel form of fungal mimicry, perhaps achieved by the ants' inability to differentiate hyphae of closely related species. Lastly, they may be mycoparasitic, including on ant cultivars, although there is currently no direct evidence supporting this hypothesis.

\section{Re-delimitation of Pterulaceae}

All the accepted genera in Pterulaceae were sampled in this study except for the monotypic Allantula. One specimen, with morphology consistent with Corner's description of Allantula diffusa, with pteruloid basidiomes borne on slender mycelial cords as curved intercalary swellings, was collected during our fieldwork (Fig. 1m). Phylogenetic reconstruction placed this specimen firmly within Phaeopterula. However, we have been unable to obtain the type specimen (no other collections authenticated exist) for more detailed analysis.

Thus, we re-delimit Pterulaceae as containing six genera: Allantula, Coronicium, Merulicium, Myrmecopterula, Phaeopterula, Pterula, and Pterulicium. 


\section{CONCLUSION}

In this study, we presented a reclassification of Pterulaceae based on morphological and phylogenetic analyses with samples from six out of seven genera previously accepted in the family. Three early diverging resupinate genera were placed in the new family Radulomycetaceae (Aphanobasidium, Radulomyces and Radulotubus); the new genus Myrmecopterula was introduced to accommodate ant associated species previously classified in Pterula; several species from the latter were also recombined in the reintroduced Phaeopterula and in Pterulicium, and finally Deflexula was synonymised with Pterulicium. Pterulaceae was thus re-delimited to accommodate seven genera Allantula, Coronicium, Merulicium, Myrmecopterula, Phaeopterula, Pterula and Pterulicium. Some species kept in Pterula might also need to be recombined since the original description was not enough to make these changes. Type specimens should be analysed considering the delimitations proposed in this study.

\section{Supplementary information}

Supplementary information accompanies this paper at https://doi.org/10. 1186/s43008-019-0022-6.

Additional file 1. Full details of all samples studied here (simplified in Table 2; as excel file)

Additional file 2. Additional phylogenetic reconstructions, including detailed analyses relating to Fig. 3

Additional file $\mathbf{3}$ Additional images of coralloid Pterulaceae and micrographs of Myrmecopterula velohortorum.

\section{Abbreviations}

BI: Bayesian inference; BPP: Bayesian posterior probability;

CTAB: cetyltrimethylammonium bromide; DNA: deoxyribonucleic acid EDTA: Ethylenediaminetetraacetic acid; ESS: Effective sample size; HPD: Highest posterior density; IUPAC: International Union of Pure and Applied Chemistry; ML: Maximum likelihood; nrlTS: nuclear ribosomal internal transcribed spacer; nrLSU: nuclear ribosomal largre subunit; PCR: polymerase chain reaction; Ph:: Phaeopterula; Pm.: Pterulicium; PSRF: Potential scale reduction factors; Pt.: Pterula; RPB2: RNA polymerase B subunit 2; U: Protein unit; UFBoot: Ultrafast bootstrap

\footnotetext{
Acknowledgements

This article is part of the PhD thesis of CALD. The authors are grateful to the managers of Parque Nacional da Tijuca (ICMBio), Floresta Nacional do Tapajós, Parque Nacional do Iguaçú, Parque Nacional da Serra dos Orgãos and Reserva Biológica Augusto Ruschi, for logistical support and collection permits. Biological Dynamics of Forest Fragmentation Project (BDFFP) for providing logistical and field support. This is publication number 770 of the BDFFP - INPA Technical Series (field reserve; location of specimen used here). We acknowledge the support of the Supercomputing Wales project, which is part-funded by the European Regional Development Fund (ERDF) via Welsh Government. We are also thankful for the kind support and loan from the following herbaria: RB (Jardim Botânico do Rio de Janeiro), FLOR (Universidade Federal de Santa Catarina), K (Royal Botanical Gardens, Kew), INPA (Instituto Nacional de Pesquisas da Amazônia), HSTM (Universidade Federal do Oeste do Pará). The researchers who kindly collect and provide samples or photos, or helped in other way to this study: Ted Schultz, M. Catherine Aime, Dennis Desjardin, D. Jean Lodge, Bitty Roy, Michael Wherley, Tobias Policha, Jesse McAlpine, Tommy Jenkinson, Rocío Manobanda, Celeste Heisecke, Altielys C.
}

Magnago, Eduardo P. Fazolino, Ariadne N. M. Furtado, Emerson L. Gumboski, Elisandro R. Drechsler-Santos, Julia Simon, Cauê Oliveira, Stefan Blaser, David J. Harries, Genivaldo Alves da Silva, Susanne Sourell, Lucie Zíbarová, André Rodrigues, Quimi Vidaurre Montoya, Louro Lima, Ocírio Juruna de Souza Pereira, Laura Martínez-Suz, Shaun Pennycook, Paul Kirk, Scott Redhead, Phillip Camarota Moura and Rafael Trevisan. A draft version of this manuscript is uploaded on the bioRxiv preprint server (bioRxiv 718809; doi: https://doi.org/10.1101/718809).

\section{Adherence to national and international regulations}

All the requirements for specimen acquisition, transportation and study in Brazil, were followed according to the Brazilian federal regulations. Dried samples were transferred between fungaria following the regulations of the Nagoya Protocol to the Convention on Biological Diversity 2011.

\section{Authors' contributions}

MAN, BTMD and CALD conceived the study; CALD and MAN obtained permits for fieldwork in Brazil; all authors carried out sample collection; CALD, LAC and BTMD performed molecular methods; CALD performed phylogenetic analyses; CALD, GWG and BTMD drafted the manuscript; all authors approved the final version of the manuscript.

\section{Funding}

CALD scholarship was provided by Coordination for the Improvement of Higher Education Personnel - Brazil, BEX 2145/15-4. Funding was provided in part from a Systematics and Taxonomy (SynTax) grant (Biotechnology and Biological Sciences Research Council, Natural Environment Research Council) to BTMD. Funding was provided in part by the National Geographic Society (No. 8317-07 to B.A. Roy and B.T.M. Dentinger) and the National Science Foundation (DEB-0841613 to B.A. Roy and B.T.M. Dentinger). The Institute of Biological, Environmental and Rural Sciences receives strategic funding from the Biotechnology and Biological Sciences Research Council (BBSRC).

\section{Availability of data and materials}

Details of the availability of the data and material used in this study can be found within the text.

DNA sequences were submitted to NCBI Genbank database (see Table 2 and Additional file 1). Alignments were deposited at TreeBase (ID: 24428). Dried specimens are deposited in the fungaria listed in the Methods section.

Ethics approval and consent to participate

Not applicable.

Consent for publication

Not applicable.

\section{Competing interests}

The authors declare that they have no competing interests.

\section{Author details}

${ }^{1}$ Institute of Biological, Environmental and Rural Sciences, Aberystwyth University, Aberystwyth, Ceredigion SY23 3DD, UK. ${ }^{2}$ Micolab, Departamento de Botânica, Centro de Ciências Biológicas, Universidade Federal de Santa Catarina, Florianópolis, Santa Catarina, Brazil. ${ }^{3}$ Department of Plant and Microbial Biology, University of Minnesota, 1445 Gortner Avenue, St Paul, MN 55108, USA. ${ }^{4}$ Natural History Museum of Utah \& Biology Department, University of Utah, 301 Wakara Way, Salt Lake City, UT 84108, USA. ${ }^{5}$ CAPES Foundation, Ministry of Education of Brazil, P.O. Box 250, Brasília, DF 70040-020, Brazil.

Received: 4 July 2019 Accepted: 8 November 2019

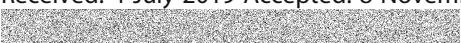

\section{References}

Bernicchia A, Gorjón SP (2010) Corticiaceae s.l. Fungi Europaei, vol 12. Candusso, Italia

Binder M, Larsson K-H, Matheny PB, Hibbett DS (2010) Amylocorticiales Ord. Nov. and Jaapiales Ord. Nov.: early diverging clades of Agaricomycetidae dominated by corticioid forms. Mycologia 102(4):865-880. https://doi.org/10. 3852/09-288 
Camacho C, Coulouris G, Avagyan V, Ma N, Papadopoulos J, Bealer K, Madden TL (2009) BLAST+: architecture and applications. BMC Bioinformatics 10(1):421. https://doi.org/10.1186/1471-2105-10-421

Capella-Gutiérrez S, Silla-Martínez JM, Gabaldón T (2009) trimAl: a tool for automated alignment trimming in large-scale phylogenetic analyses. Bioinformatics 25(15):1972-1973. https://doi.org/10.1093/bioinformatics/ btp348

Chernomor O, von Haeseler A, Minh BQ (2016) Terrace aware data structure for Phylogenomic inference from Supermatrices. Systematic Biology 65(6):9971008. https://doi.org/10.1093/sysbio/syw037

Corner EJH (1950) A monograph of Clavaria and allied genera, vol 1. Annals of Botany memoirs, Dawsons, London

Corner EJH (1952a) Addenda Clavariacea I. two new Pteruloid genera and Deflexula. Annals of Botany 16(2):269-291

Corner EJH (1952b) Addenda Clavariacea II. Pterula and Pterulicium. Annals of Botany 16(4):531-569

Corner EJH (1952c) Generic names in Clavariaceae. Trans British Mycol Society 35(4):285-298

Corner EJH (1966) Clavarioid genera and Thelephora from the Congo. Bulletin du Jardin botanique de l'État a Bruxelles 36(Fasc. 3):257-279

Corner EJH (1967) Clavarioid fungi of the Solomon Islands. In: Proceedings of the Linnean Society of London, 1967. vol 2. Oxford University Press, Oxford, UK, pp 91-106

Corner EJH (1970) Supplement to "a monograph of Clavaria and allied genera". Beihefte zur Nova Hedwigia 33:1-299

Dentinger BTM (2014) Nomenclatural novelties. Index Fungorum 98:

Dentinger BTM, Gaya E, O'Brien H, Suz LM, Lachlan R, Díaz-Valderrama JR, Koch RA, Aime MC (2016) Tales from the crypt: genome mining from fungarium specimens improves resolution of the mushroom tree of life. Biol J Linnean Society 117(1):11-32. https://doi.org/10.1111/bij.12553

Dentinger BTM, Lodge DJ, Munkacsi AB, Desjardin DE, McLaughlin DJ (2009) Phylogenetic placement of an unusual coral mushroom challenges the classic hypothesis of strict coevolution in the Apterostigma pilosum group ant-fungus mutualism. Evolution 63(8):2172-8. https://doi.org/10.1111/j.15585646.2009.00697.x

Dentinger BTM, Margaritescu S, Moncalvo J-M (2010) Rapid and reliable highthroughput methods of DNA extraction for use in barcoding and molecular systematics of mushrooms. Mol Ecol Resour 10(4):628-633. https://doi.org/10. 1111/j.1755-0998.2009.02825.x

Dentinger BTM, McLaughlin DJ (2006) Reconstructing the Clavariaceae using nuclear large subunit rDNA sequences and a new genus segregated from Clavaria. Mycologia 98(5):746-762. https://doi.org/10.3852/mycologia.98.5.746

Dogma IJ (1966) Philippine Clavariaceae. I. The pteruloid series. Philippine Agriculturist 49(10):844-61.

Donk MA (1949) New and revised nomina generica conservanda proposed for Basidiomycetes (Fungi). Bull bot Gdns Buitenzorg 18:83-168

Donk MA (1954) The generic names proposed for Hymenomycetes - III - " Clavariaceae". Reinwardtia 2(3):441-493

Donk MA (1963) The generic names proposed for Hymenomycetes. XIII: additions and corrections to parts I-IX. XII. Taxon 12(3):113-123. https://doi.org/10.2307/ 1217202

Donk MA (1964) A conspectus of the families of Aphyllophorales. Persoonia 3(2): 199-324

Doty M (1948) Proposals and notes on some genera of clavarioid fungi and their types. Lloydia 11:123-128

Fries EM (1821) Systema Mycologicum volumen I, vol 1. Ex Officina Berlingiana, Lund \& Greifswald

Fries EM (1825) Systema Orbis Vegetabilis Typographia academia. Lundae, Sweden

Fries EM (1830) Eclogae fungorum, praecipue ex herbariis germanorum de scriptorum. Linnaea

Harsh SNK, Singh YP, Gupta HK, Mushra BM, McLaughlin DJ, Dentinger B (2005) A new culm rot disease of bamboo in India and its management. J Bamboo Rattan 4:387-398

Hennings P (1900) Fungi monsunenses. In: Warburg O (ed) Monsunia; Beiträge zur Kenntniss der Vegetation des Süd- und Ostasiatischen Monsungebietes. vol 1. W. Engelmann, Leipzig, p 38.

Hennings P (1904) Fungi amazonici II, a cl. Ernesto Ule collecti. Hedwigia 43: 242-273

Hibbett DS (2007) After the gold rush, or before the flood? Evolutionary morphology of mushroom-forming fungi (Agaricomycetes) in the early twenty-first century. Mycol Res 111 (9):1001-1018. doi:https://doi.org/https:// doi.org/10.1016/j.mycres.2007.01.012

Hoang DT, Chernomor O, von Haeseler A, Minh BQ, Vinh LS (2018) UFBoot2: Improving the Ultrafast Bootstrap Approximation. Mol Biol Evol 35(2):518522. https://doi.org/10.1093/molbev/msx281

https://www.nature.com/articles/nmeth.4285\#supplementary-information Kalyaanamoorthy S, Minh BQ, Wong TKF, von Haeseler A, Jermiin LS (2017) ModelFinder: fast model selection for accurate phylogenetic estimates. Nat Methods 14:587. https://doi.org/10.1038/nmeth.4285

Katoh K, Standley DM (2013) MAFFT multiple sequence alignment software version 7: improvements in performance and usability. Mol Biol Evol 30(4): 772-780. https://doi.org/10.1093/molbev/mst010

Kearse M, Moir R, Wilson A, Stones-Havas S, Cheung M, Sturrock S, Buxton S, Cooper A, Markowitz S, Duran C, Thierer T, Ashton B, Meintjes P, Drummond A (2012) Geneious Basic: An integrated and extendable desktop software platform for the organization and analysis of sequence data. Bioinformatics 28(12):1647-1649. https://doi.org/10.1093/ bioinformatics/bts199

Larsson A (2014) AliView: a fast and lightweight alignment viewer and editor for large datasets. Bioinformatics 30(22):3276-3278. https://doi.org/10.1093/ bioinformatics/btu531

Larsson K-H (2007) Re-thinking the classification of corticioid fungi. Mycol Res 111(9):1040-1063

Larsson K-H, Larsson E, Kõljalg U (2004) High phylogenetic diversity among corticioid homobasidiomycetes. Mycol Res 108(09):983-1002

Leal-Dutra CA (2015) Contribuições Taxonômicas e Filogenéticas ao Estudo de Pterulaceae (Agaricales) Coraloides. Universidade Federal de Santa Catarina, Florianópolis

Leal-Dutra CA, Neves MA, Griffith GW, Reck MA, Clasen LA, Dentinger BTM (2018) Reclassification of Parapterulicium Corner (Pterulaceae, Agaricales), contributions to Lachnocladiaceae and Peniophoraceae (Russulales) and introduction of Baltazaria gen. nov. MycoKeys 37. https://doi.org/10.3897/mycokeys.37.26303

Liu YJ, Whelen S, Hall BD (1999) Phylogenetic relationships among ascomycetes: evidence from an RNA polymerse II subunit. Mol Biol Evol 16(12):1799-1808

Lloyd CG (1919) Mycological notes. Mycol Writings 5(60):15

Maas Geesteranus R (1964) Notes on Hydnums - II. Persoonia-Molecular Phylogeny and Evolution of Fungi 3(2):155-192

Matheny PB (2005) Improving phylogenetic inference of mushrooms with RPB1 and RPB2 nucleotide sequences (Inocybe; Agaricales). Mol Phylogenet Evol 35(1):1-20

Matheny PB, Curtis JM, Hofstetter V, Aime MC, Moncalvo J-M, Ge Z-W, Yang Z-L, Slot JC, Ammirati JF, Baroni TJ (2006) Major clades of Agaricales: a multilocus phylogenetic overview. Mycologia 98(6):982-995

McLaughlin DJ, McLaughlin EG (1972) Pure culture studies of fruiting and sporulation in a clavarioid fungus, Pterula sp. Mycologia 64(3):599-608. https://doi.org/10.2307/3757875

McLaughlin DJ, McLaughlin EG (1980) A new species of Pterula (Aphyllophorales) with corticioid characteristics. Can J Bot 58(12):1327-1333. https://doi.org/10. 1139/b80-163

McLaughlin EG, McLaughlin DJ, Adson DE (1978) Developmental anatomy of a dimitic basidiomycete, Pterula sp. Can J Bot 56(3):288-296. https://doi.org/10. 1139/b78-036

Mueller UG, Kardish MR, Ishak HD, Wright AM, Solomon SE, Bruschi SM, Carlson AL, Bacci M (2018) Phylogenetic patterns of ant-fungus associations indicate that farming strategies, not only a superior fungal cultivar, explain the ecological success of leafcutter ants. Mol Ecol 27(10):2414-2434. https://doi. org/10.1111/mec.14588

Müller K (2005) SeqState. Appl Bioinform 4(1):65-69. https://doi.org/10.2165/ 00822942-200,504,010-00008

Munkacsi A, Pan J, Villesen P, Mueller U, Blackwell M, McLaughlin D (2004) Convergent coevolution in the domestication of coral mushrooms by fungus-growing ants. Proc R Soc Lond B: Biol Sci 271(1550):1777-1782

Nguyen L-T, Schmidt HA, von Haeseler A, Minh BQ (2015) IQ-TREE: A fast and effective stochastic algorithm for estimating maximum-likelihood phylogenies. Mol Biol Evol 32(1):268-74. https://doi.org/10.1093/molbev/ msu300

Pereira JS, Costa RR, Nagamoto NS, Forti LC, Pagnocca FC, Rodrigues A (2016) Comparative analysis of fungal communities in colonies of two leaf-cutting ant species with different substratum preferences. Fungal Ecol 21:68-75. doi: https://doi.org/https://doi.org/10.1016/j.funeco.2016.03.004 
Remsberg RE (1940) A New Species of Pistillaria on Rice Straw. Mycol 32(5):4. https://doi.org/10.1080/00275514.1940.12017444

Roberts P (1999) Clavarioid fungi from Korup National Park. Cameroon. Kew Bull: $517-539$

Rogers DP (1949) Nomina Conservanda Proposita and Nomina Confusa-Fungi: Nomina Conservanda. I. Farlowia 3:425-493

Rogers DP (1950) Nomina Conservanda Proposita and Nomina Confusa-Fungi Supplement. Farlowia 4:15-43

Saccardo PA, Saccardo D (1905) Sylloge Fungorum, vol XVII. Patavii, Italy

Schultz TR (2007) The fungus-growing ant genus Apterostigma in Dominican amber. In: Snelling R, BL Fisher, PS Ward (ed) Advances in ant systematics (Hymenoptera: Formicidae): homage to E. O. Wilson - 50 years of contributions., vol 80. Memoirs of the American Entomological Institute. American Entomological Institute, Gainesville, FL, pp. 425-436.

Simmons MP, Ochoterena H (2000) Gaps as characters in sequence-based phylogenetic analyses. Syst Biol 49(2):369-81. https://doi.org/10.1093/sysbio/ 49.2.369

Spegazzini C (1921) Mycetes chilenses. Boletín de la Academia Nacional de Ciencias en Córdoba 25:124

Sumner S, Aanen DK, Delabie J, Boomsma JJ (2004) The evolution of social parasitism in Acromyrmex leaf-cutting ants: a test of Emery's rule. Insectes Sociaux 51(1):37-42. https://doi.org/10.1007/s00040-003-0723-z

Vilgalys R, Hester M (1990) Rapid genetic identification and mapping of enzymatically amplified ribosomal DNA from several Cryptococcus species. J Bacteriol 172(8):4238-4246

Villesen P, Mueller UG, Schultz TR, Adams RM, Bouck AC (2004) Evolution of antcultivar specialization and cultivar switching in Apterostigma fungus-growing ants. Evolution 58(10):2252-2265

Zhao C-L, Chen H, He S-H, Dai Y-C (2016) Radulotubus resupinatus gen. et sp. nov. with a poroid hymenophore in Pterulaceae (Agaricales, Basidiomycota). Nova Hedwigia 102(3-4):3-4

\section{Publisher's Note}

Springer Nature remains neutral with regard to jurisdictional claims in published maps and institutional affiliations.

Ready to submit your research? Choose BMC and benefit from:

- fast, convenient online submission

- thorough peer review by experienced researchers in your field

- rapid publication on acceptance

- support for research data, including large and complex data types

- gold Open Access which fosters wider collaboration and increased citations

- maximum visibility for your research: over $100 \mathrm{M}$ website views per year

At BMC, research is always in progress.

Learn more biomedcentral.com/submissions 